Repository of the Max Delbrück Center for Molecular Medicine (MDC) Berlin (Germany)

http://edoc. molc-berlin.de/13938/

\title{
Germline transgenesis in rodents by pronuclear microinjection of sleeping beauty transposons
}

Ivics, Z., Mates, L., Yau, T.Y., Landa, V., Zidek, V., Bashir, S., Hoffmann, O.I., Hiripi, L., Garrels, W., Kues, W.A., Boesze, Z., Geurts, A., Pravenec, M., Ruelicke, T., Izsvak, Z. 


\title{
Germline transgenesis in rodents by pronuclear
}

\section{microinjection of Sleeping Beauty transposons}

\author{
Zoltán Ivics ${ }^{1, *}$, Lajos Mátés ${ }^{2}$, Tien Yin Yau ${ }^{3}$, Vladimír Landa ${ }^{4}$, Vaclav Zidek ${ }^{4}$, Sanum Bashir ${ }^{5}$, \\ Orsolya I. Hoffmann ${ }^{6}$, László Hiripi ${ }^{6}$, Wiebke Garrels ${ }^{7}$, Wilfried A. Kues ${ }^{7}$, Zsuzsanna Bősze ${ }^{6}$, Aron \\ Geurts $^{8}$, Michal Pravenec $^{4, *}$, Thomas Rülicke ${ }^{3, *}$ and Zsuzsanna Izsvák ${ }^{5, *}$
}

1 Division of Medical Biotechnology, Paul Ehrlich Institute, Langen, Germany

2 Biological Research Centre, Hungarian Academy of Sciences, Szeged, Hungary

3 Institute of Laboratory Animal Science, University of Veterinary Medicine Vienna, Vienna, Austria

$4 \quad$ Institute of Physiology, Academy of Sciences of the Czech Republic, Prague, Czech Republic

5 Max Delbrück Center for Molecular Medicine, Berlin, Germany

$6 \quad$ Agricultural Biotechnology Center, Gödöllö, Hungary

7 Friedrich-Loeffler-Institut, Institut für Nutztiergenetik, Neustadt, Germany

8 Department of Physiology, Medical College of Wisconsin, WI, USA

* For correspondence:
Zoltan Ivics
Paul Ehrlich Institute
Paul Ehrlich Str. 51-59
D-63225 Langen
Germany
Email: zoltan.ivics@pei.de

Zsuzsanna Izsvak

Max Delbrück Center for Molecular Medicine

Robert Rossle Strasse 10

13125 Berlin

Germany

Email: zizsvak@mdc-berlin.de
Thomas Rülicke

University of Veterinary Medicine

Veterinärplatz 1

A-1210 Vienna

Austria

Email: Thomas.Ruelicke@vetmeduni.ac.at

Michal Pravenec

Institute of Physiology

Academy of Sciences of the Czech Republic

Videnska 1083

CZ-14220 Prague

Czech Republic

Email: pravenec@biomed.cas.cz

\section{Key words:}

genetics, functional genomics, animal models, gene insertion, germline, transgenic, microinjection, transposon

\section{Key references:}

Katter K, Geurts AM, Hoffmann O, Mátés L, Landa V, Hiripi L, Moreno C, Lazar J, Bashir S, Zidek V, Popova E, Jerchow B, Becker K, Devaraj A, Walter I, Grzybowksi M, Corbett M, Filho AR, Hodges MR, Bader M, Ivics Z, Jacob HJ, Pravenec M, Bosze Z, Rülicke T, Izsvák Z. Transposon-mediated transgenesis, transgenic rescue, and tissue-specific gene expression in rodents and rabbits. FASEB J. 2013, 27(3):930-41.

Garrels W, Mátés L, Holler S, Dalda A, Taylor U, Petersen B, Niemann H, Izsvák Z, Ivics Z, Kues WA.Germline transgenic pigs by Sleeping Beauty transposition in porcine zygotes and targeted integration in the pig genome. PLoS One. 2011, 6(8):e23573.

Mátés L, Chuah MK, Belay E, Jerchow B, Manoj N, Acosta-Sanchez A, Grzela DP, Schmitt A, Becker K, Matrai J, Ma L, Samara-Kuko E, Gysemans C, Pryputniewicz D, Miskey C, Fletcher B, VandenDriessche T, Ivics Z, Izsvák Z. Molecular evolution of a novel hyperactive Sleeping Beauty transposase enables robust stable gene transfer in vertebrates. Nat Genet. 2009, 41(6):753-61. 
We describe a protocol for high-efficiency germline transgenesis and sustained transgene expression in two important biomedical models, the mouse and the rat, using the Sleeping Beauty transposon system. The procedure is based on co-injection of synthetic mRNA encoding the SB100X hyperactive transposase together with circular plasmid DNA carrying a transgene construct flanked by binding sites for the transposase, into the pronuclei of fertilized oocytes. Upon translation of the transposase mRNA, enzyme-mediated excision of the transgene cassettes from the injected plasmids followed by permanent genomic insertion produces stable transgenic animals. Generation of a germline-transgenic founder animal by using this protocol takes approximately three months. Transposon-mediated transgenesis compares favorably in terms of both efficiency and reliable transgene expression to classic pronuclear microinjection, and offers comparable efficacies to lentiviral approaches, without limitations on vector design, issues of transgene silencing, and the toxicity and biosafety concerns of working with viral vectors. Transpositionmediated gene delivery can easily be implemented by any laboratory, thereby providing an attractive method to genetically modify animals for biomedical and biotechnological purposes. 


\section{INTRODUCTION}

Mice and rats are the most common species used as experimental model systems for the analysis of physiological traits, to investigate the pathogenesis of human diseases and for developing new therapies. Both species offer unique advantages for use in biomedical research such as their versatility and the abundance of available resources, including mutant archives produced by the large-scale N'-ethyl-N'-nitrosourea (ENU) mutagenesis screens, the International Knockout Mouse Consortium (IKMC), the International Gene Trap Consortium (IGTC) and the European Mouse Mutant Archive (EMMA) $)^{1-6}$. A large number of inbred strains have been successfully generated for mice and rats; these genetically standardized and phenotypically characterized strains are valuable and well documented tools available for the scientific community. The availability of the full genome sequence of the mouse and the rat further strengthened their position as leading mammalian model $\operatorname{organisms}^{7,8}$. A comprehensive comparison with the previously decoded human genome revealed a high similarity in the genomic sequences presumably reflecting similarities in gene function between humans and rodents ${ }^{9}$.

The Norway rat (Rattus norvegicus) was the first mammal domesticated for scientific research ${ }^{10}$. Laboratory rats are widely used in pharmacological and toxicological testing but also in basic research for modelling physiological processes of human organ systems. Its larger size and often closer similarity to human biology would seem to make the rat a better experimental tool than the mouse (Mus musculus). However, despite the many advantages of rats as model organisms, the laboratory mouse is currently the predominant mammalian species in biomedical research. This is mainly due to the availability of several genetic modification technologies developed and continuously advanced in mice over the past 30 years, which enabled gene trapping and the introduction of targeted mutations ${ }^{11-15}$.

Mutagenesis is currently the most frequently used method to examine gene function and regulation, and several strategies have been developed to experimentally induce mutations into rodent germlines. Mutagenesis by homologous recombination for producing knockout and knockin animals was limited to mouse models owing to the successful isolation and culture of pluripotent 
embryonic stem cells (ESCS). After more than two decades of intensive effort, pluripotent rat ESC lines have been successfully isolated and cultured ${ }^{13,16}$. The application of the $2 \mathrm{i}$ cell culture system developed for murine ESCs has further improved the derivation of rat ESCs ${ }^{17,18}$, and enabled for the first time generating a targeted mutation in the rat genome by homologous recombination ${ }^{19}$. However, the use of ESCs to modify the rat genome is still very challenging. Therefore, apart from the common technologies for genetic engineering, new strategies to manipulate the mouse and the rat genome have been recently developed. New tools for targeted mutagenesis that can not only be applied in ESCs but are efficient enough for genome engineering directly in living embryos include zinc finger nucleases (ZFNs), transcription activator-like effector nucleases (TALENs) and the CRISPR/Cas system ${ }^{20-26}$.

\section{Germline transgenesis in rodents}

Germline transgenesis is an important procedure for the generation of heritable, loss-of-function or gain-of-function phenotypes in model species for investigations into the functions of biological pathways as well as for animal biotechnology. Since 1981, the most routinely applied method in mice has been pronuclear DNA-injection ${ }^{27}$. This methodology has also been adapted to rats and is performed in a very similar way ${ }^{28,29}$. For mice, pronuclear injection of transgenes often yields more than $20 \%$ founders among the live offspring ${ }^{27,30}$. In rats the reported efficiency of classical microinjection is much lower than in mice, possibly due to the significantly lower percentage of ova surviving the microinjection procedure ${ }^{28,31,32}$. Standard pronuclear injection of a transgene involves the introduction of a small number of identical copies of a linearized DNA molecule into a freshly fertilized oocyte. Linearization of transgene constructs is important, because the integration frequency is much higher for linearized than for circular DNA molecules ${ }^{33}$. However, linearized molecules recombine with each other immediately after pronuclear injection and before chromosomal integration to form concatemeres ${ }^{34}$. Consequently, the gene copy number per transgenic locus is unpredictable and unique for each founder line. In addition, transgenic concatemeres can persist in a nonintegrated form for several cell divisions, resulting in unequal 
transgene distribution between the blastomeres of the early embryo ${ }^{35}$. Therefore, a high percentage of transgenic founders produced by pronuclear injection are genetic mosaics ${ }^{36}$. A further limitation associated with this technology is that multicopy concatemers are prone to undergo transcriptional silencing ${ }^{37}$, thereby compromising the production of transgenic stocks with reliable spatio-temporal patterns of transgene expression. In addition, integration of pronuclear injected transgenes often causes severe chromosomal alterations at the chromosomal integration site(s), including deletions, duplications and translocations ${ }^{38-40}$.

Another alternative approach to producing transgenic rodents is sperm-mediated gene transfer (SMGT) combined with intracytoplasmic sperm injection (ICSI) ${ }^{41-43}$. In this procedure, spermatozoa are subjected to disruption of their head membranes, hence the need for the sophisticated ICSI for fertilization. The resulting frequency of founders produced by this technique is comparable to standard pronuclear injections. An improved efficiency of SMGT was demonstrated for large constructs cloned in $\mathrm{YACs}^{44}$. Furthermore, founders produced by SMGT are only rarely genetic mosaics ${ }^{44}$. However, there are major concerns regarding the impact of the procedure on the genetic material of the sperm and, consequently, on the genome of the resulting transgenic animal ${ }^{45,46}$.

Higher transgenic rates were reported by injecting recombinant lentiviral vectors into the periviteline space of ova in various animal models, including rodents and certain livestock species $^{47,48}$. The use of lentiviral vectors for transgenesis has been optimized in rats and resulted in $22 \%$ average frequency of producing founders. Although this frequency certainly represents an improvement over classic pronuclear microinjection of naked DNA, it is much lower than the reported $80 \%$ in mice ${ }^{47,49}$. Several problems with using lentiviral vectors remain, such as genetic mosaicism due to vector integration into the genome in later developmental stages, limitations of transgene size, vector-related toxicity, transcriptional silencing of proviral insertions by cellular mechanisms and preferential insertion into endogenous genes. Thus, methods with the capacity to yield more robust germline transmission rates coupled with predictable transgene expression 
patterns, technical ease and greater safety would significantly improve transgenic studies in mammalian models.

\section{Transgenesis with the Sleeping Beauty transposon}

Similarly to retroviruses, DNA transposons integrate into the chromosomes of the host cells, a feature that forms the basis of their use for gene delivery. In nature, these elements contain a gene encoding a transposase enzyme flanked by inverted terminal repeats (ITRs) that carry binding sites for the transposase. Under laboratory conditions, transposons are applied as bi-component vector systems, in which a DNA sequence of interest can be cloned between the transposon ITRs and mobilized by providing the transposase enzyme in trans, as an expression plasmid or as in vitro synthesized mRNA (Fig. 1A). During transposition, the transposase excises the genetic element from its donor plasmid and integrates it into a chromosomal locus (Fig. 1B). Based on fossil record of transposons that were active $>10$ million years ago in diverse fish species, an ancient transposon was "awakened" (molecularly reconstructed) and named Sleeping Beauty (SB), after the Grimm brothers' fairy tale ${ }^{50}$. SB was the first transposon shown to be capable of efficient transposition in vertebrate cells, thereby opening new avenues for genetic engineering in animal models (reviewed in ref. 51).

The SB system combines the advantages of retroviral vectors (permanent gene insertion into recipient genomes) with those of naked DNA molecules (simple and safe production and application). Because transposition is a cut-and-paste mechanism that does not involve reverse transcription, transposon-based vectors can tolerate larger and more complex transgenes. The SB system is not strictly limited by the size of expression cassettes ${ }^{52}$. Indeed, inserts as large as bacterial artificial chromosomes (BAC) were recently shown to transpose with SB at reasonable

efficiencies in mouse $\mathrm{ESCs}^{53}$. When performing transgenesis, a single copy transgene insertion, which is not disturbing endogenous gene functions is desirable. Chromosomal integration of SB transposons is nearly random at the genome level resulting in $\sim 60 \%$ of the SB transposon 
integrations being intergenic ${ }^{54-57}$. Furthermore, transposons have been shown to efficiently deliver a wide variety of transgene cassettes (reviewed in refs. 51, 58 and 59).

Because the transposase is only transiently present in the cell, the integrated transposon is stable (i. e., will not undergo further rounds of transposition), thereby rendering transposons easily controllable, conditional DNA delivery tools that can be used for versatile applications, including germline gene transfer. We have recently developed a hyperactive variant of the SB transposase, called SB100X, by in vitro evolution ${ }^{60}$. SB100X supports efficient germline transgenesis in mice ${ }^{60,61}$, rats $^{61}$, rabbits $^{61,62}$ and pigs ${ }^{63,64}$. We optimized the SB100X-mediated protocol by carefully titrating the relative amounts of transposase and transposon to obtain optimal rates of transgenesis to generate founders, and extensively evaluated it for efficacy, toxicity, mosaicism, germline transmission, insertion site preferences, transgene copy number and silencing. Genotyping of numerous transgenic lines produced by SB-transposition demonstrated single-copy integrations of the transposon as expected from the cut-and-paste integration reaction catalyzed by the SBtransposase ${ }^{61}$. The numbers of integrations per genome were shown to be dependent on and hence controllable by the concentration of both components of the transposon system in the injection cocktail. The best results in terms of frequency of founder animals with mostly single integrations were achieved by a reduction of the amount of transposon plasmid DNA ${ }^{61}$.

One of the most important aspects of using this protocol is that no major mosaicism was observed, and transgene expression was maintained for several generations in all species tested. The lack of mosaicism is in sharp contrast to any other current, non-viral or viral approach for transgenesis. This is likely due to the very nature of transgene integration: transposition results in precise (the ends of the integrating DNA are well defined) genomic integration of monomeric transgene units within a short timeframe following administration, thereby minimizing mosaicism. Furthermore, unlike retroviral vectors ${ }^{48,65-67}$, SB100X-catalyzed transgene integration does not seem to trigger transcriptional silencing ${ }^{56,61}$. Therefore, the application of the Sleeping Beauty transposon system described here will significantly enhance the mouse and rat genomic toolbox. 


\section{Limitations}

DNA transposons, including SB, are regulated by overproduction inhibition, which means that overexpression of the transposase has a negative effect on transposition ${ }^{56,68}$. The practical consequence of this phenomenon is that an optimal ratio of transposon donor plasmid and transposase mRNA needs to be established. As a rule of thumb, the injection mixture should contain $5 \mathrm{ng} / \mu \mathrm{l} \mathrm{SB100X}$ mRNA and $0.4 \mathrm{ng} / \mu \mathrm{l}$ transposon donor plasmid for an SB vector of a total size of $\sim 6.1 \mathrm{~kb}$ containing $\mathrm{a} \sim 2.5 \mathrm{~kb}$ transgene cassette ${ }^{60}$. For larger transgenes, the concentration of the donor plasmid in the microinjection mixture has to be increased to maintain optimal molar ratios between transposon and transposase. It has been found that embryos tolerate concentrations of transposon donor plasmid up to $2 \mathrm{ng} / \mu \mathrm{l}$ in mice ${ }^{60}$.

\section{Experimental Design}

The generation of transgenic rodents by SB-mediated transgenesis is achieved through microinjection of a plasmid carrying a gene of interest, cloned between the ITRs of SB, and synthetic transposase mRNA (Fig. 1) into the pronucleus of a fertilized oocyte, with frequencies of transgenic founders of $50-70 \%$ for both mice and rats ${ }^{61}$. The protocol consists of the following major steps:

\section{Preparation of Sleeping Beauty transposon components for microinjection (Steps 1-26).}

These steps include molecular cloning of a gene of interest into SB transposon vectors and purification of the resulting plasmid construct; preparation of mRNA encoding the transposase by in vitro transcription, and preparation of a nucleic acid mixture consisting of the purified transposon plasmid carrying the ITR-flanked transgene and the transposase mRNA.

Transgenesis with Sleeping Beauty in mice (Steps 27-39) and rats (Steps 40-74). These steps include preparation of donor mice, collection of ova, microinjection of the nucleic acid mixture into ova and transfer of the microinjected ova into surrogate mothers.

Genotyping of transgenic animals (Steps 75-100). These steps include PCR-based analysis of F0 as well as F1 offspring to establish founders and germline transmission. A simple, quick PCR 
test can be applied to determine the presence of integrated transposon sequences from genomic DNA samples. The PCR primers amplify sequences in the left ITR of SB; thus, this protocol can be universally applied irrespective of the gene of interest that was cloned in the SB vector. In order to assess copy numbers of integrated transposons and map the genomic integration sites, a ligationmediated PCR procedure is applied ${ }^{69}$. The procedure consists of a restriction enzyme digest of the genomic DNA, ligation of an oligonucleotide adapter to the ends of the fragmented DNA, PCR amplification of a transgene/genomic DNA junction in two rounds of PCR with primers specific to the adapter and to the ITRS of the SB transposon, and sequencing of the junctions to map the insertion to the reference genome ${ }^{70}$. Finally, a locus-specific PCR is applied to distinguish and track the individual integrations in the F1 and later generations.

\section{MATERIALS}

\section{Reagents}

\section{Animals}

- Two different strains are required, the donor strain to produce ova and the recipient strain, which is used to provide pseudopregnant surrogate mothers. Donors: predominantly used inbred strains are C57BL/6 mice and F344 rats. Surrogate mothers and sterile males: recipients of embryos are usually outbred due to their superior fertility. Examples of preferred strains are NMRI and ICR mice at an age of 8-20 weeks and Wistar, Sprague Dawley and Long-Evans rats at an age of 11-18 weeks. ! Caution Animal experiments must be approved by and conducted according to institutional and national regulations.

\section{Molecular biology reagents}

- mMessage mMachine ${ }^{\circledR}$ T7 kit (Invitrogene/Ambion, cat no. AM1344)

- Plasmid DNA preparation kit (Qiagen, cat no. 27106)

- Agarose (DNase, RNase none detected) (Sigma-Aldrich, cat no. A4718) 
- Ethidium bromide $1 \%$ solution in water (Sigma-Aldrich, cat no. E7637) ! Caution This is a hazardous chemical. Avoid contact with skin, eyes and airways.

- Clal restriction endonuclease (New England Biolabs, cat no. R0179S)

- Bfal restriction endonuclease (New England Biolabs, cat no. R0568S)

- Dpnll restriction endonuclease (New England Biolabs, cat no. R0543S)

- Taq DNA polymerase, provided with PCR buffer (10 x) and $\mathrm{MgCl}_{2}(25 \mathrm{mM})$ (New England Biolabs, cat no. M0267S)

- dNTP (10 mM) (New England Biolabs, cat no. N0447S)

- Injection buffer, EmbryoMax® (Millipore, cat no. MR-095-10 F)

- Sodium chloride (Sigma-Aldrich, cat no. S3014)

- Sodium acetate 3 M pH 5.5 (RNase-free) (Invitrogen/Ambion, cat no. AM9740)

- RNaseZap (Invitrogene/Ambion, cat no. AM9780)

- 2-propanol (ROTH, cat no. 6752.1)

- Ethanol (RNase-free) (MERCK, cat no. 108543)

- Water (RNase-free, filtered) (Sigma-Aldrich, cat no. W4502) CRITICAL The use of filtered RNase-free water is recommended for solutions coming in contact with the injection material.

- Phenol/chloroform/isoamyl alcohol, Roti®-Phenol/C/I (ROTH, cat no. A156.2) ! Caution This is a hazardous chemical. Avoid contact with skin, eyes and airways.

- Chloroform/isoamyl alcohol, Roti®-C/I (ROTH, cat no. X984.2)! Caution This is a hazardous chemical. Avoid contact with skin, eyes and airways.

- Diethylpyrocarbonate (DEPC) (Sigma-Aldrich, cat no. D5758) ! Caution This is a hazardous chemical. Avoid contact with skin, eyes and airways.

- 5 x TBE buffer, Nuclease-free (Sigma-Aldrich, cat no. 93306)

- TE buffer (Sigma-Aldrich, cat no. 93283)

- T4 DNA ligase, provided with ligase buffer (10x) (New England Biolabs, cat no. M0202S)

- 100-bp DNA Ladder (Thermo Scientific, cat no. SM0242) 
- 100-10.000-bp DNA Ladder (Thermo Scientific, cat no. SM0331)

- QIAqick Gel Extraction kit (Qiagen, cat no. 28706)

- pGEM-T Vector Systems (Promega, cat no. A3600)

- Transposon donor plasmids are available from Addgene: $\mathrm{pT} 2 / \mathrm{BH}$ (http://www.addgene.org/26556/) or pT2/HB (http://www.addgene.org/26557/).

- Transposase expression plasmids: pCMV(CAT)T7-SB100X is available from Addgene (http://www.addgene.org/34879/) and pcGlobin2-SB100X is available from Dr. Zsuzsanna Izsvak, Max Delbrück Centrum for Molecular Medicine, Berlin.

\section{Animal work}

- Equine chorionic gonadotropin/Pregnant mare's serum gonadotropin (PMSG) (Folligon®, Intervet, cat no. 113064 R1 or Sergon ${ }^{\circ}$, Bioveta a.s., reg no. 96/116/92-C)

- Human chorionic gonadotropin (hCG) (Chorulon®, cat no. 044976 or Intervetor Pregnyl®, N.V.Organon, reg no. 56/279/91-C/C)

- M2 medium (Sigma-Aldrich, cat no. M7167, St. Luis, USA)

- M16 medium (Sigma-Aldrich, cat no. M7292)

- G-IVF PLUS medium (Vitro Life, cat. no. 10136)

- Mineral oil (Sigma-Aldrich, cat no. M8410-500ML)

- Penicillin G (Sigma-Aldrich, cat no. P3032)

- Streptomycin sulfate salt (Sigma-Aldrich, cat no. S1277)

- Hyaluronidase (Sigma-Aldrich, cat no. H3506-100MG)

- Ketasol® Ketamine (aniMedica, cat no. 14.057.1004)

- Xylasol@ Xylazine (aniMedica, cat no. 14.073.1011)

- Metacam® MeloxicamXylapan (Xylazinum 20mg/ml, Vetoquinol, cat no. 96/010/01 C)

- Narketan (Ketaminum 100 mg/ml, Vetoquinol, cat no. 96/010/01 C)

- Eye ointment (Oleovit, Fresenius Kabi cat no. V0005652/10) 
- Sigmacote (Sigma-Aldrich, cat no. SL2-100ML) ! Caution Corrosive, flammable, harmful in contact with eyes, skin and airways.

- Sulfuric acid (Sigma-Aldrich, cat no. 320501-1L)! Caution Corrosive, harmful in contact with skin.

- Hydrofluoric acid (Sigma-Aldrich, cat no. 339261-100ML) ! Caution Corrosive, harmful in contact with skin.

\section{Equipment}

\section{For molecular biology}

- Refrigerated centrifuge capable of high speed $(12000 \times g)$ (Thermo Scientific, cat no. 75008162)

- Water bath, $37^{\circ} \mathrm{C}$ (Thermo Scientific, cat no. 2824)

- NanoDrop® ND-2000 Spectrophotometer (Thermo Scientific, cat no. 91-ND-2000)

- Milli-Q Water Purification System (Merck Millipore, cat no. ZRXQ003T0)

- 1.5-mL tubes, free of DNase and RNase (Eppendorf, cat no. 0030123.328)

- Pipette tips, free of DNase and RNase [Eppendorf, cat no. 0030077.504 (0.1- $10 \mu \mathrm{l})$, cat no. $0030077.539(2-20 \mu \mathrm{l})$, cat no. $0030077.555(2-200 \mu \mathrm{l})$, cat no. $0030077.571(50-1000 \mu \mathrm{l})]$

- Thermal cycler capable of temperature increments for touchdown PCR (Thermo Scientific, cat no. TCA0001)

- Electrophoresis apparatus including running chamber, well combs, gel tray and power supply (BioRad, cat no. 164-5050)

- 100-ml glass flask for gel preparation (SIMAX, cat no. B1812)

\section{Capillaries}

- Capillary tubes, length 75 mm, capacity $60 \mu \mathrm{L}$ (KAVALIER Ltd.)

- Borosilicate glass tubes without filament to produce transfer capillaries for embryo transfer (Science Products, cat no. GB150-10) ! Caution Sharp objects should be disposed into approved containers. 
- Commercial injection capillaries (Femtotip II, Eppendorf, cat no. 5242957000) ! Caution Sharp objects should be disposed into approved containers.

- Commercial holding capillaries (VacuTip, Eppendorf, cat no. 5175108000) ! Caution Sharp objects should be disposed into approved containers.

- Glass tubes to produce injection capillaries (Narishige GD-1) ! Caution Sharp objects should be disposed into approved containers.

- Glass tubes to produce holding capillaries (Narishige G-1 or G-100) ! Caution Sharp objects should be disposed into approved containers.

- Pipette Puller (Sutter Instrument P-97 or Narishige PC-10)

- Microforge (H. SAUR, cat no. A031102 or Narishige, cat no. MF-900)

- Glass cutter (Hilgenberg, cat no. 4018303)

\section{Embryo production, microinjection and embryo transfer}

- Petri dishes 100, 60, 30 mm, sterile (Sarstedt, cat nos. 82.1474, 82.1194, 82.1135)

- $22 \mu \mathrm{m}$ syringe filter (Sigma-Aldrich, cat no. Z359904-50EA)

- Stereomicroscopes with large working distance (Leica MZ 75, Leica MZ 125, SZX9 Olympus)

- Blunt hypodermic flushing needle (32G Point Style $251 \mathrm{~mm}$, Hamilton)

- Vibration-damped microscope table

- Inverted microscope with DIC (Zeiss Axiovert 200 or Olympus IX70)

- Microinjector for holding capillary (CellTram Oil, Eppendorf, cat no. 5176000025)

- Microinjector for injection capillary (CellTram Vario, Eppendorf, cat no. 5176000033)

- FemtoJet injector (Eppendorf, cat no. 5247 000.013)

- Eppendorf microloader, $0.5 \mu \mathrm{L}$ - $20 \mu \mathrm{L}$ (Eppendorf, cat. no. 335242956003 )

- 2x micromanipulator (TransferMan NK2, Eppendorf, cat no. 5188000012 or NT-88, Narishige)

- Laminar hood (preferred with heated surface and with integrated transmission and reflecting microscope (IVF-Workstations, K-Systems, Kivex Biotech Ltd) 
- Tubing with mouthpiece and capillary holder (Eppendorf, cat no. 5176 190.002)

- Concave ground superfrost microscope slides (VWR International, cat no. 631-9475)

- Microscope slides, 25 x 75 mm (Sigma-Aldrich, Product no. C8902-1CS)

- Cover glass, 24 x 60 mm (Sigma-Aldrich, Product no. C9056-1CS)

- Glue stick (KORES S.A.)

- In vitro fertilization 4-well plate (Nunc, cat no. 144444)

- Watchmaker forceps (07.60.05, Medicon or Sigma-Aldrich, cat no. F6521-1EA) ! Caution Sharp objects.

- Surgical instruments ! Caution Sharp objects.

- Shaving razors, stainless steel surgical prep blades (Personna, cat. no. 74-0001) ! Caution Sharp objects.

- Hair clipper (Hyundai PC 550, Oster)

- Micro-dissecting scissors (Sigma-Aldrich, cat no. S3271-1EA)! Caution Sharp objects.

- Nontraumatic suture material (Chirmax, EP2.5-USP, sterile, cat no. 6319)

- Michel wound clips (Medin 7.5 x 1.75 mm, cat. no. 13291 0391)

- Gauze sponges 7.5 x $7.5 \mathrm{~cm}$ (PANEP MULLTEX DIN 61630)

- Vliwasoft sterile dressing 7.5 x 7.5150 ks (sterile) (Lohmann-Rauscher 12082)

- Nontraumatic and absorbable suture material (Vicryl 6-0, V301G, Ethicon)

- Disposable skin stapler (Precise, 3M Health Care, cat no. 78-8083-1351-0)

\section{REAGENT SETUP}

Preparation of the transposase mRNA. Synthetic mRNA encoding the SB100X transposase can be produced (Step 17) from either the pCMV(CAT)T7-SB100X or the pcGlobin2-SB100X plasmids $^{60}$ (see Reagents). The latter vector supports in vitro synthesis of SB100X mRNA containing zebrafish $\beta$-globin 5'- and 3'-UTRs and a 30-mer synthetic poly(A) sequence, from a T7 $\operatorname{promoter}^{71}$. 
DEPC treatment of water. Add $1 \mathrm{ml}$ DEPC to $1 \mathrm{~L}$ Milli-Q water to make a $0.1 \%$ (vol/vol) solution and shake vigorously. Continuously stir the solution for 12 hours at room temperature $\left(\sim 20^{\circ} \mathrm{C}\right)$. Autoclave it for $1 \mathrm{~h}$ to remove any trace amount of DEPC, as residual DEPC reacts with purine residues in RNA.

$\mathrm{NaCl}$ solution for oligonucleotide annealing. Prepare a $500 \mathrm{mM} \mathrm{NaCl}$ stock solution in Milli-Q water, and sterilize with autoclaving or filtration. Prepare the working solution by diluting the stock 10x in sterile TE buffer. Keep frozen at $-20^{\circ} \mathrm{C}$.

Quality control of synthetic mRNA on agarose gel. Clean the running chamber, gel tray, comb and flask for gel preparation with $70 \%$ (vol/vol) ethanol and decontaminate them from RNases with RNaseZap. Rinse the reagent off with RNase-free Milli-Q water (DEPC-treated). Incubate $1 \mu$ of in vitro synthesized mRNA in $10 \mu$ injection buffer for 1 hour at $37^{\circ} \mathrm{C}$ and run on an RNase-free $1 \%$ (wt/vol) agarose gel.

TBE. DEPC cannot be used directly to treat Tris buffers. To prepare TBE, dilute the nuclease-free 5 x TBE (see Reagents) in DEPC-treated water.

Hormones. Dissolve lyophilized powder of PMSG and of hCG hormones for superovulation in Aqua pro injectione to the final concentration of $50 \mathrm{IU} / \mathrm{ml}$. Store solutions refrigerated $\left(4-6^{\circ} \mathrm{C}\right)$ for no longer than 2 weeks, or as frozen aliquots at $-80^{\circ} \mathrm{C}$.

Hyaluronidase solution. Dissolve hyaluronidase (lyophilized powder) in M2 medium to the concentration of $10 \mathrm{mg} / \mathrm{ml}$ (stock solution) or the working concentration of $1 \mathrm{mg} / \mathrm{ml}$ and store at -20 ${ }^{\circ} \mathrm{C}$ until use. 
Media. Prepare M2 and M16 culture media by adding Penicillin G (60 mg/L) and Streptomycin (50 $\mathrm{mg} / \mathrm{L})$. Sterilize with a $22 \mu \mathrm{m}$ syringe filter, aliquot and store media refrigerated $\left(4-6^{\circ} \mathrm{C}\right)$ for no longer than 4 weeks.

Isolation of genomic DNA of F0 animals from tail or ear biopsies. A simple and reliable protocol for DNA isolation from tissue samples is available at The Jackson Laboratory page (http://jaxmice.jax.org/support/genotyping/tail phenol.html).

\section{EQUIPMENT SETUP}

Chambers for microinjection. The chamber is made from a microscope slide with a 15-mm hole drilled in the center of the slide glued to a cover glass that forms the bottom of the chamber. Store the chambers in a Petri dish (diameter $100 \mathrm{~mm}$ ) and sterilize by UV irradiation before use. Alternatively, use heat sterilized concave ground microscope slides.

Injection and holding capillaries. Both injection and holding capillaries are commercially available. However, if transgenic animals are routinely generated in a laboratory, it is recommended to produce your own capillaries by using a puller and a microforge. The specific pulling conditions depend on the glass tubes and specific puller equipment used. Store the GD-1 glass tubes and pulled injection capillaries (with filament) in a way that avoids dust accumulation. The finely drawn injection capillary should have an outer diameter at the tip of about $1 \mu \mathrm{m}$. If the tip is sealed, push it slightly on the holding capillary to break the tip open. Alternatively, it can be opened prior to loading of the injection solution by submersing the very tip of the capillary into $20 \%$ (vol/vol) hydrofluoric acid for 8-12 seconds. Stop the reaction by washing the tip in sulfuric acid for 2-3 seconds, followed by washing in water (biotechnology performance certified) for 2-3 seconds, and then in pure ethanol for 2-3 seconds. Optionally, silicon-coat the injection capillary (Sigmacote for 5-7 seconds) and wash in water (biotechnology performance certified) for 2 to 3 seconds. Bend the tips of injection and holding capillaries (2-3 mm long) to an angle of $15^{\circ}$ (using a microforge). Flame- 
polish the opposite end of the injection- and the holding-capillaries over the flame of the burner (for smooth insertion of capillaries into the microinstrument holders).

The holding capillaries are pulled with specific pulling conditions from glass tubes without filament (G-1, G-100). Use a microforge to break the pulled glass at an outer diameter of about 70 $\mu \mathrm{m}$ and fire-polish the tip to an inner diameter of about 15-30 $\mu \mathrm{m}$. If necessary, heat-sterilize both capillaries at $200^{\circ} \mathrm{C}$ for 2 hours.

CRITICAL The selection of optimal injection micropipettes significantly affects the speed of DNA injection, survival rate of injected ova, and degree of control of pronuclear injection.

Hand-operated manipulation and transfer capillaries. Hand-pull transfer and manipulation capillaries from borosilicate glass tubes heated over the flame of a burner. Use a glass cutter to score the pulled segment at an internal diameter of about $300 \mu \mathrm{m}$ (manipulation capillary) and 100 $\mu \mathrm{m}$ (transfer capillary) (diameters are measured using the scale of a stereo microscope), then break and fire-polish the end. This must be done very quickly in order to avoid sealing the tip. If necessary, sterilize capillaries by heat or UV irradiation before use. Transfer capillaries can be used mouth-controlled or hand-controlled. For the latter, connect the prepared capillary with rubber tubing (length 1.5-2 cm, closed with a knot on one end) fitting to the diameter of pipette barrels. CRITICAL Selection of optimal transfer capillaries enables fast, precise, and effective manipulation of embryos without any damage or loss throughout the entire procedure.

\section{PROCEDURE}

CRITICAL At each step of the protocol use RNase-free plasticware and wear gloves while handling reagents and samples to prevent RNase contamination.

Preparation of RNase-free transposon (ITR-flanked transgene) donor plasmid $\square$ TIMING 2-4 h

1 Clone your gene of interest between the ITRs of an SB transposon donor plasmid by standard molecular cloning procedures. 
2 Transfer at least $5 \mu \mathrm{g}$ of transposon donor plasmid in $400 \mu \mathrm{l}$ TE buffer into a $1.5 \mathrm{ml}$ tube, and add $400 \mu \mathrm{l}$ phenol/chloroform/isoamyl alcohol to the tube. ! Caution This is a hazardous chemical. Avoid contact with skin, eyes and airways.

3 Vortex the tube for $15 \mathrm{~s}$ and leave it on the bench for $2 \mathrm{~min}$. Repeat this step 3 times to completely inactivate residual RNase.

4 Centrifuge at $12000 \times g$ for $5 \mathrm{~min}$ at room temperature.

5 Transfer the top layer to a new, RNase-free $1.5 \mathrm{ml}$ tube and add $400 \mu$ l chloroform/isoamyl alcohol. ! Caution This is a hazardous chemical. Avoid contact with skin, eyes and airways.

6 Vortex for $15 \mathrm{~s}$ and centrifuge at $12000 \times g$ for $5 \mathrm{~min}$ at room temperature.

7 Transfer the aqueous top layer, containing the DNA, to a new, RNase-free $1.5 \mathrm{ml}$ tube, add $1 / 10$ volume of $3 \mathrm{M}$ sodium acetate and 2.5 volumes of ethanol, and precipitate the DNA for $30 \min$ at $-20^{\circ} \mathrm{C}$.

8 Spin down at $12000 \times g$ for 15 min at $4{ }^{\circ} \mathrm{C}$ and discard the supernatant.

9 Wash the pellet in cold $70 \%$ (vol/vol) ethanol (RNase-free) by keeping the ethanol on the pellet for $10 \mathrm{~min}$, centrifuge at $12000 \times \mathrm{g}$ for $1 \mathrm{~min}$ at $4{ }^{\circ} \mathrm{C}$, and discard the supernatant. Repeat this step to completely remove any residual chemicals that may not be tolerated by the embryos.

CRITICAL STEP DEPC is not tolerated by the embryos and RNase-free solutions that come in contact with the injected material should be purified by filtration. Therefore, use the filtered, RNasefree water for the preparation of $70 \%$ ethanol.

10 Air-dry the pellet for 5-10 minutes and resuspend it in $100 \mu \mathrm{l}$ EmbryoMax® injection buffer.

11 Measure the concentration of the plasmid DNA using a NanoDrop® spectrophotometer.

12 Make a $50 \mathrm{ng} / \mu \mathrm{l}$ dilution of the plasmid in EmbryoMax® injection buffer. This solution can be used later for the preparation of the final injection mixture (Steps 25-26).

Pause Point The plasmid stock and its $50 \mathrm{ng} / \mu \mathrm{l}$ dilution can be stored (preferably at $-80{ }^{\circ} \mathrm{C}$ ) until use for up to 2 years. 
13 Thaw the plasmid DNA immediately before the preparation of the microinjection mixture (Step 25).

\section{Preparation of the transposase mRNA $\square$ TIMING 10-14h}

14 Linearize at least $2 \mu \mathrm{g}$ of the pcGlobin2-SB100X plasmid with Clal digestion. $1 \mu \mathrm{g}$ of linearized plasmid will be necessary for one round of mRNA synthesis. Check complete linearization on a $1 \%(\mathrm{wt} / \mathrm{vol})$ agarose gel.

CRITICAL STEP Supercoiled plasmid DNA runs faster, whereas open circular plasmid runs slower on agarose gel than the linear form. Following full digestion, bands corresponding to the open circular and supercoiled forms of the plasmid should be no longer visible on the gel. Consequently, linearized plasmid DNA produces a single band corresponding to the size of the plasmid when compared to a linear DNA ladder size marker.

15 Prepare the digested plasmid RNase-free by phenol/chloroform extraction as described in Steps 2-10. In Steps 2 and 5, set the volumes of the digested plasmid DNA, the phenol/chloroform/isoamyl alcohol and the chloroform/isoamyl alcohol to $100 \mu$ l each. This will decrease the liquid volume during precipitation and improve DNA recovery.

16 Measure the concentration of the linearized plasmid DNA using a NanoDrop ${ }^{\circledR}$ spectrophotometer.

17 Synthesize the mRNA using the mMessage mMachine ${ }^{\circledR} T 7$ kit following the manufacturer's instructions.

18 After mRNA synthesis, perform the Turbo DNase treatment and phenol/chloroform extraction suggested in the kit manual, with the modification that after the isopropanol precipitation following the phenol/chloroform extraction, wash the pellet twice in cold $70 \%$ (vol/vol) ethanol. Use filtered, RNase-free water for the preparation of $70 \%$ ethanol. Air-dry the pellet for 5-10 minutes.

19 Resuspend the mRNA in $20 \mu$ filtered, RNase-free water. 
20 Measure the concentration of the in vitro synthesized mRNA using a NanoDrop ${ }^{\circledR}$ spectrophotometer. The typical yield is around $1 \mu \mathrm{g} / \mu \mathrm{l}$.

21 Prepare a $1 \%$ (wt/vol) agarose gel using nuclease-free TBE buffer, Milli-Q water treated with DEPC and agarose powder. ! Caution DEPC is a hazardous chemical. Avoid contact with skin, eyes and airways.

22 Load $1 \mu$ l of the in vitro synthesized mRNA (Step 19) in RNA loading buffer (supplied with the mMessage mMachine ${ }^{\circledR}$ T7 kit) and a DNA size marker and run the gel. The SB100X mRNA prepared using the T7 promoter on the Clal-digested pcGlobin2-SB100X runs on a normal agarose gel between 700-800 bp (Fig. 2, lane 1). Typically, the in vitro synthesized mRNA runs as one band on a non-denaturing gel (Fig. 2, lane 1). Alternatively, two bands may be visible (Fig. 2, lane 2) due to the formation of secondary structures.

\section{? TROUBLESHOOTING}

23 Prepare $50 \mathrm{ng} / \mu$ l dilution of the mRNA (Step 19) in EmbryoMax® injection buffer for later use. CRITICAL STEP It is advisable to test new batches of the EmbryoMax® injection buffer for accidental presence of RNase (see Reagent Setup) as the manufacturer does not guarantee that it is RNase-free. Fig. 2, lane 2 shows the result of an injection buffer test without visible signs of mRNA degradation.

Pause Point The in vitro synthesized mRNA and its $50 \mathrm{ng} / \mu \mathrm{l}$ dilutions can be stored at $-80^{\circ} \mathrm{C}$ until use.

24 Thaw the $50 \mathrm{ng} / \mu \mathrm{l}$ mRNA solution immediately before the preparation of the microinjection mixture.

CRITICAL STEP Repeated thawing and freezing of mRNA stocks may cause mRNA degradation.

\section{Preparation of the microinjection mixture $\square$ TIMING $1 \mathrm{~h}$}

CRITICAL In order to prepare the final microinjection mixture, specific amounts of SB100X mRNA and transposon donor plasmid have to be mixed to reach their optimal final concentrations. For 
both mice and rats, the best working injection mixture contains $0.4 \mathrm{ng} / \mu \mathrm{l}$ transposon donor plasmid and $5 \mathrm{ng} / \mu \mathrm{l} \mathrm{SB100X} \mathrm{mRNA}^{60}$.

25 Prepare $2 X$ concentration solutions: $0.8 \mathrm{ng} / \mu \mathrm{l}$ of transposon donor plasmid (from the stock solution prepared in Step 12) and $10 \mathrm{ng} / \mu \mathrm{l}$ of transposase mRNA (from the stock solution prepared in EmbryoMax® injection buffer in Step 23) in EmbryoMax® injection buffer.

26 Mix the $2 X$ concentration solutions at 1:1 ratio to create the final microinjection mixture.

Prepare 5-10 $\mu \mathrm{l}$ aliquots of the final microinjection mixture.

Pause Point Aliquots of the microinjection mixture may be stored at $-80^{\circ} \mathrm{C}$ for a couple of months.

\section{Mouse transgenesis: Preparation of the ovum donors $\square$ IIMING 3 days}

CRITICAL Mouse transgenesis is described in Steps 27-39.

CRITICAL The staff of a transgenic lab and animal facility need to have substantial experience in reproductive biology, methods of assisted reproduction, cell culture techniques, mouse genetics and molecular biology.

CRITICAL The animals need to be maintained and treated under conditions which are suitable in terms of the hygienic quality. The use of healthy animals in SPF (specific pathogen free) or SOPF (specific opportunistic pathogen free) conditions will assure the best results regarding efficacy of the method and allows for the possibility of unrestricted distribution of the resulting founders to other facilities.

CRITICAL The donor strain has to be selected according to the appropriate genetic background for the transgene and the ability for efficient superovulation. Inbred strains are preferred, because they have a defined genetic background. However, they are generally less efficient in all crucial aspects of production of ova, microinjection and embryonic development than outbred or hybrid animals.

27 Apply hormonal treatment to increase the number of ova per donor. Superovulate mice by intraperitoneal (i.p.) application of 5 IU PMSG and 46-48 h later (directly before mating) with 5 IU hCG between 9 a.m. and 10 a.m. (Fig. 3). 
28 Pair mice for mating. Put females into the male's cage for mating and not vice versa. Putting males in a new cage may induce exploration behavior and delay the start of copulation. The optimal dosage of both hormones can vary depending on the mouse strain used and the age of the animals.

CRITICAL STEP The most appropriate age of donors of different genetic backgrounds needs to be empirically determined. For example, F1-hybrid and BALB/c females are used as donors as young adults at about 7 weeks of age. In contrast, the superovulation of C57BL/6 females is most efficient as juveniles during their prepubescent stage of development.

\section{? TROUBLESHOOTING}

\section{Isolation of ova $\square$ TIMING 1 hour}

29 Equilibrate M16 medium in the incubator (at $37^{\circ} \mathrm{C}, 5 \% \mathrm{CO}_{2}$ ) for about $12 \mathrm{~h}$ before use. Prewarm M2 medium, mineral oil, glass slides and diluted hyaluronidase solution on a warming plate $\left(37^{\circ} \mathrm{C}\right)$ before use. Pre-warm injection anesthetics, analgesics and eye ointment to room temperature.

30 In the morning of the day intended for embryo transfer to the recipient mice, harvest the ova from dissected oviducts of donor mice by flushing with M2 medium about $23 \mathrm{~h}$ after hCG application and mating (Fig. 3A). At this time the ova are still in or partly released from the cumulus complex and both pronuclei are clearly visible.

\section{? TROUBLESHOOTING}

31 Remove the remaining sticky cumulus cells of the flushed ova by incubation in the $1 \mathrm{mg} / \mathrm{ml}$ hyaluronidase solution for 3-5 min in a Petri dish. Examine the size of the pronuclei under the microscope, and store the ova in M2 medium on a warming plate until the pronuclei are of the appropriate size for injection (about $15 \mu \mathrm{m}$ in diameter) (Step 34). The optimal time window for pronucleus injection lasts about $3 \mathrm{~h}$ from when the male pronucleus reaches $15 \mu \mathrm{m}$ in diameter to shortly before the disappearance of the fully-developed pronuclei. The diameter 
of the pronucleus can be estimated by comparing it to the diameter of the ova (which is about $80 \mu \mathrm{m})$. We recommend implementation of all steps of ova preparation in a laminar flow bench with a $37^{\circ} \mathrm{C}$ heated surface.

CRITICAL STEP Dissect the oviduct and flush the ova in cumulus complexes immediately after sacrificing the donor female. Avoid changes of osmolarity due to evaporation of the medium during culture or injection. The resulting shrinking of the ova will complicate microinjection.

\section{Microinjection of ova $\square$ TIMING 2-3 hours}

CRITICAL RNA is very unstable and sensitive to ribonucleases. Use gloves during all steps of handling the injection cocktail. All materials including pipette tips, injection buffer, reaction tube, DNA preparations and injection capillaries have to be clean and free of ribonucleases.

32 Place about 30 ova into the northern part of a small drop of M2 medium in the injection chamber (see Equipment Setup) covered by pre-warmed mineral oil.

33 Keep the transposon DNA/transposase mRNA-injection mixture from Step 26 at $4{ }^{\circ} \mathrm{C}$ during usage. Fill the injection capillary with approx. $1 \mu$ injection mixture using a microloader or by inverting the capillary into the injection buffer and allowing it to fill-up by capillary action. Ensure that the tip of the injection capillary is open.

CRITICAL STEP Ova are not adherent to the surface of the slide and therefore need to be fixed by a holding capillary for injection.

34 By using an inverted microscope and micromanipulator, select the paternal pronucleus based on its larger size, and fix the ovum with the holding capillary in such a way that the pronucleus is located near the horizontal axis of the ovum (Fig. 4). Insert the injection capillary into the pronucleus and inject until the pronucleus visibly swells (about 1-2 pl). The diameter of the pronucleus will increase from about $15 \mu \mathrm{m}$ to $20 \mu \mathrm{m}$ ). Since the plasma membrane of a mouse ovum is extremely elastic, penetration usually does not occur until the tip of the injection capillary is inside the pronucleus.

\section{? TROUBLESHOOTING}


35 Move each ovum after successful microinjection into the southern part of the oil-covered M2 drop until all ova are treated.

CRITICAL STEP Further details about pronuclear injection can be found in refs. 72 and 73. ? TROUBLESHOOTING

\section{Preparation of surrogate mothers $\square$ TIMING 1-3 days}

36 Mate surrogate females monogamously or bigamously to vasectomized, sterile males of the same outbred stock as the females (alternatively, mutant strains expressing male infertility and asthenozoospermia can be used if their mating behavior is proved to be normal and if they produce a vaginal plug) in the afternoon of the day before microinjection (Fig. 3A), to produce recipients for the injected embryos on the next day.

CRITICAL STEP Avoid pairing mice too early (e.g. in the morning) because any female mouse that had undergone estrus on the previous night could immediately mate and may lose the vaginal plug by the next morning. Since the presence of a vaginal plug is a marker for a successful mating, this could result in undetected pseudopregnant females. Calculate the number of matings necessary to provide the required number of surrogate mothers. The estrus cycle of mice is about 4 days and therefore $25 \%$ of mated females are expected to have a vaginal plug. To increase the frequency of plugged females, they can be stimulated $48 \mathrm{~h}$ before mating by exposure to male pheromones (Whitten effect $)^{74}$. This can be done with dirty bedding from the stud male's cage.

\section{Embryo transfer $\square$ TIMING 2 hours}

37 Identify pseudopregnant recipients by vaginal plug control on the next morning after mating. Since the microinjection is performed in the morning, injected ova can be re-transplanted in the afternoon of the same day (Fig. 3A). If not enough surrogate mothers are available, the remaining ova can be cultured overnight in equilibrated M16 medium in an incubator and retransplanted the next morning as 2-cell stage embryos into $0.5 \mathrm{dpc}$ pseudopregnant females. Use the instruments shown in Fig. 5A for embryo transfer. 
38 Anesthetize the pseudopregnant female with $10 \mathrm{mg} / 100 \mathrm{~g}$ body weight of Ketamine (Ketasol) and $0.4 \mathrm{mg} / 100 \mathrm{~g}$ body weight of Xylazine (Xylasol) (Fig. 5B). Other anesthesia protocols are possible depending on the availability of appropriate equipment (inhalation anesthesia) or local regulations ${ }^{75}$.

CRITICAL STEP Perform embryo transfer (following step) only after the animal has reached surgical tolerance under general anesthesia. Surgical tolerance is tested by the withdrawal reflex after pinching the hind foot. In order to avoid hypothermia, place the animals on a warming plate during surgery and until recovery from the anesthesia. Cover the eyes with eye ointment to protect them from drying.

CRITICAL STEP Pseudopregnancy can be confirmed by the swollen ampulla.

39 Transfer microinjected ova or two-cell stage embryos via the infundibulum into the oviduct as shown and described in Fig. 5C-K. Although there is no transmigration of mouse embryos from one uterine horn into the other, we recommend unilateral embryo transfer into the right oviduct. Transfer 20-30 injected embryos per female: too few offspring can result in bad brood care and infanticide by the mother. Further details about embryo transfer in mice can be found in refs. 73,76 and 77.

CRITICAL STEP In order to avoid pain after surgery, implement an appropriate analgesic treatment for example by subcutaneous injection of $0.05 \mathrm{mg}$ meloxicam $/ 100 \mathrm{~g}$ body weight.

CRITICAL STEP Avoid exposing surrogate mothers to pheromones of an unfamiliar male for at least the first 4 days after embryo transfer. Exposure would have a drastic impact on the female's reproductive state, and may result in termination of the early pregnancy and return of the estrus cyclicity (Bruce effect) ${ }^{78}$.

? TROUBLESHOOTING

Rat transgenesis: Preparation of vasectomized males $\square$ TIMING 14 days

CRITICAL Rat transgenesis is described in Steps 40-74. 
40 Anaesthetize male rats from outbred Long Evans stock (80 to 90 days old) with i.p. injections of ketamine ( $80 \mathrm{mg} / \mathrm{kg}$ body weight) and xylazine ( $4 \mathrm{mg} / \mathrm{kg}$ body weight).

41 Shave lower abdomen with clippers and sterilize the shaved region with $70 \%$ (vol/vol) ethanol. With a pair of curved forceps and scissors, make a cut across the lower abdomen (the incision in the midline wall should be about $1 \mathrm{~cm}$ wide).

42 Using blunt forceps and scissors to separate the vas deferens from the surrounding tissue, gently grasp the vas deferens with the forceps, lift it out of the incision, and cut off the section in the loop of the vas deferens.

43 Return the vas deferens gently back inside the abdominal cavity, and repeat the procedure on the other side. Sew the incision in the body wall with separate stitches and close up the skin with three Michel clips.

44 Keep rats in a warm place, supervise and monitor them until they are recovered from anesthesia. Allow males to recover for two weeks before using them for inducing pseudopregnant females.

\section{Superovulation of female donors $\square$ TIMING 3 days}

45 For stimulating of ovum donors for microinjections, select a group of 6-8 female rats (40 to 90 days old) and inject them by an i.p. injection of 20 IU of PMSG (SERGON) in $0.4 \mathrm{ml}$ of diluted gonadotrophin (see Reagent Setup) between 9 a.m. and 10 a.m. (Fig. 3B).

46 For ovulation and fertilization, inject 25 IU hCG i.p. (Pregnyl) in $0.5 \mathrm{ml}$ of diluted gonadotrophin) (see Reagent Setup) 48-49 hours after SERGON injection (Fig. 3B), transfer the injected rats individually into cages with a fertile male and mate them overnight.

47 On the next morning, between 9 a.m. and 10 a.m., check rats for vaginal plugs; mark positive rats on the tail and place them into clean cages.

CRITICAL STEP The day of plug observation is Day 1 of pregnancy.

Recovery and manipulation of fertilized ova $\square$ TIMING 1 hour per 8 superovulated donors 
48 Sacrifice the superovulated (donor) females with detected vaginal plugs (Step 47) by cervical dislocation on Day 1 of pregnancy, between 2 p.m. to 4 p.m. (Fig. 3B). Sterilize their abdomen with $70 \%$ (vol/vol) ethanol and open the abdominal cavity with scissors.

49 Hold the proximal part (about $1 \mathrm{~mm}$ ) of the uterine horn with forceps and dissect the oviduct with the help of fine scissors. Wash the oviduct in 300-400 $\mu \mathrm{L}$ of M2 medium (warmed to room temperature) and transfer it into a $100 \mu \mathrm{L}$ drop of M2 medium placed on the lid of a 60 mm sterile tissue culture Petri dish (each oviduct in its individual drop of M2 medium, place 4 oviducts separately on one lid).

50 Place two $200 \mu \mathrm{L}$ drops with hyaluronidase solution besides each drop with oviducts and transfer the Petri dish lid with oviducts under a dissecting microscope. Fix the ampulla portion of the oviduct with fine forceps and tear it open with second fine forceps.

51 Release cumulus complexes with ova, transfer them (with a wide manipulation capillary) into the drop with hyaluronidase and incubate cumulus complexes in this drop for 3-5 minutes (incubate all cumulus complexes from one donor in one drop with hyaluronidase).

52 With the help of gentle pipetting (with a narrow manipulation capillary) free ova from the cumulus cells, wash them in fresh M2 medium and transfer all fertilized ova into $5 \mu \mathrm{L}$ drops of M2 medium placed on the bottom of the injection chamber.

53 Place the microinjection chamber with ova under the inverted microscope (Olympus IX70, equipped with DIC optic, 10x eyepieces, 5x, 20x and 40x objectives). Record the number of fertilized ova, showing two pronuclei and a $2^{\text {nd }}$ polar body.

54 Place the injection chamber with ova under the stereomicroscope, transfer a group of ova collected from a single donor from the $\mathrm{M} 2$ medium into a drop of $\mathrm{CO}_{2}$-preincubated G-IVF PLUS medium at room temperature, wash them by repeated pipetting in this drop, and transfer them into a well (containing $300 \mu \mathrm{L}$ of $\mathrm{CO}_{2}$-preincubated G-IVF PLUS medium) of a 4-well plate.

55 Keep the ova in the incubator in $6 \% \mathrm{CO}_{2}$ at $37{ }^{\circ} \mathrm{C}$ for 1 to 4 hours until microinjection. Microinjection is done between 4 p.m. and 8 p.m. on Day 1. 
Pronuclear injection $\square$ TIMING 1-3 hours per 100-200 ova

56 Place a $5 \mu$ drop of M2 medium in the center of the microinjection chamber, and cover the drop with mineral oil.

57 For DNA microinjection, transfer a group of 25-30 fertilized ova from the 4-well plate into a $300 \mu \mathrm{L}$ drop of M2 medium, placed on the lid of a $60 \mathrm{~mm}$ Petri dish, wash them and place them in the M2 medium drop in the microinjection chamber.

58 Mount the chamber with ova under the inverted microscope equipped for microinjection (Olympus IX70 with DIC-optic, Narishige micromanipulators, FemtoJet injector and CellTram Air for operation of the holding microcapillary).

59 Fill the injection capillary with $1 \mu \mathrm{L}$ of injection mixture (Step 26) with the help of a microloader.

60 Install holding and injection capillaries into basic position close to each other in the very center of the drop of M2 medium situated in the center of the chamber and with all ova in the lower half of the drop (carry out the installation at magnification 10x eyepieces and $5 \mathrm{x}$ objective).

61 Fix a selected fertilized ovum showing distinct pronuclei and a $2^{\text {nd }}$ polar body to the holding capillary under the DIC-optic (magnification 10x eyepieces and 20x objective), and microinject the ovum (Fig. 6A) so that the volume of the injected pronucleus visibly increases. Microinjection is done between 4 p.m and 8 p.m.; inject 100-200 ova per session (Fig. 3B).

CRITICAL STEP Injection capillaries are changed whenever the process of microinjection is out of order (clogged or broken tips, increased number of lysed ova, remnants of cytoplasm or pronuclear membranes on the surface of microinjection capillaries).

62 Collect all injected ova in the upper half of the working field (Fig. 6A), while the rest (unfertilized ova and all abnormal and degenerated ova) is left in the lower half of the field.

\section{? TROUBLESHOOTING}




\section{In vitro culture of injected ova $\square$ TIMING 15-20 hours}

63 Transfer the injection chamber with injected ova under the stereomicroscope and collect all surviving injected ova with a manipulation capillary.

64 Transfer and wash the ova in a drop of $\mathrm{CO}_{2}$-preincubated G-IVF PLUS medium at room temperature, and place them into a well (containing $300 \mu \mathrm{L}$ of $\mathrm{CO}_{2}$-preincubated G-IVF PLUS medium) of a 4-well plate.

65 Insert the 4-well plates into the incubator in $6 \% \mathrm{CO}_{2}$ at $37{ }^{\circ} \mathrm{C}$ and keep the injected ova there for 15 to 20 hours.

\section{Preparation of pseudopregnant recipients (surrogate mothers) $\square$ TIMING 1 day}

66 Use sexually mature Wistar female rats (90-120 days old) as foster mothers. On the day of microinjection (Step 61), check 10 to 40 female rats for the stage of the estrus cycle by vaginal flushing (between 1 p.m. and 2 p.m., Fig. 3B), and place those showing strong sign of proestrus (mass of nucleated epithelial cells typical for proestrus) into the cages together with two vasectomized Long-Evans males overnight.

67 On the next morning, between 9 a.m. and 10 a.m., use only the rats showing vaginal plugs as foster mothers. Use them for embryo transfer on the same day as when vaginal plugs are detected (between 10 a.m. and 11 a.m., Fig. 3B).

\section{? TROUBLESHOOTING}

Embryo transfer into recipient foster mothers $\square$ TIMING 1 hour per 8 recipient foster mothers CRITICAL Embryo transfer of injected 2-cell embryos is done between 9 a.m. to 10 a.m. in order to avoid 2-cell block. To reduce the surgery trauma only unilateral transfer into the oviduct is made.

68 Anesthetize recipient foster mother by i.p. injection of Narketan (150 mg/kg) and Xylapan (2 $\mathrm{mg} / \mathrm{kg}$ ), shave the abdomen (left flank, $4 \times 2 \mathrm{~cm}$ ), sterilize with $70 \%$ (vol/vol) ethanol and open the abdominal cavity (cut into skin and body wall, 1-2 cm). 
69 Pull out the abdominal fat with the ovary, oviduct and proximal part of uterine horn and fix them on a strip $(3 \times 2 \mathrm{~cm})$ of woven wound dressing soaked in saline so that the infundibulum is clearly visible.

70 Place the stereomicroscope in the laminar flow box, make a hole in the ovarian bursa (with the help of two pairs of fine forceps and avoiding bleeding) and fix the infundibulum on a fine strip of paper ( $2 \mathrm{~mm} \times 5 \mathrm{~mm}$ ) cut off from the paper towel.

71 Take the 4-well plate with injected embryos from the incubator (Step 65), transfer it under the stereomicroscope placed inside the laminar flow box, and select 2-cell embryos for the transfer into recipient foster mother.

\section{? TROUBLESHOOTING}

72 Aspirate 2-cell embryos into the manipulation capillary with narrow opening; transfer 10 to 14 embryos to one recipient foster mother, in a minimal volume of G-IVF PLUS medium, with each 2-cell embryo placed between small air bubbles.

73 Insert the manipulation capillary with 2-cell embryos into the infundibulum (close to the first bend of the oviduct), and gently expel the medium with 2-cell embryos into the oviduct.

74 Gently place abdominal fat with ovary, oviduct and uterine horn back into the abdominal cavity, close up the abdominal wall with a suture and the skin with wound clips. Place the foster mother in a cage and keep her in a warm place for 1-2 hours until she wakes up and is mobile.

CRITICAL STEP Avoid exposing surrogate mothers to pheromones of an unfamiliar male for at least the first 4 days after embryo transfer. Exposure would have a drastic impact on the female's reproductive state, and may result in termination of the early pregnancy and return of the estrus cycle (Bruce effect) ${ }^{79}$.

\section{? TROUBLESHOOTING}


Genotyping of transgenic animals by confirming transposon insertions by PCR $\square$ TIMING

2.5 hours

CRITICAL If the transposon includes a visibly expressed (fluorescent) marker, early embryos and F0 offspring can be identified by fluorescence emission (Fig. 4C and Fig. 6B-D). However, transgene integration and germline transmission must be confirmed by DNA analysis.

75 Isolate genomic DNA of F0 animals from tissue samples (see Reagent Setup), and set up a

PCR reaction in a $25 \mu$ volume containing the following components:

\begin{tabular}{lll}
\hline Component & Amount per reaction & Final \\
\hline $\mathrm{PCR}$ buffer $(10 \mathrm{x})$ & $2.5 \mu \mathrm{l}$ & $1 \mathrm{x}$ \\
$\mathrm{MgCl}_{2}(25 \mathrm{mM})$ & $1.5 \mu \mathrm{l}$ & $1.5 \mathrm{mM}$ \\
dNTP $(10 \mathrm{mM})$ & $0.5 \mu \mathrm{l}$ & $0.2 \mathrm{mM}$ \\
Primer SB short $(10 \mathrm{pmol} / \mu \mathrm{l})($ Table 1$)$ & $0.8 \mu \mathrm{l}$ & $8 \mathrm{pmol}$ \\
Primer Tbal rev $(10 \mathrm{pmol} / \mu \mathrm{l})($ Table 1$)$ & $0.8 \mu \mathrm{l}$ & $8 \mathrm{pmol}$ \\
Genomic DNA & $1 \mu \mathrm{l}$ & $\sim 200 \mathrm{ng}$ \\
Taq DNA polymerase & $0.4 \mu \mathrm{l}$ & $2 \mathrm{U}$ \\
$\mathrm{H}_{2} \mathrm{O}$ & $17.5 \mu \mathrm{l}$ & - \\
\hline
\end{tabular}

76 Run the PCR reaction using the following conditions:

\begin{tabular}{l|c|c|c|c} 
Cycle number & Denature & Anneal & Extend & Hold \\
\hline 1 & $94^{\circ} \mathrm{C}, 5 \mathrm{~min}$ & & & \\
$2-31$ & $94^{\circ} \mathrm{C}, 1 \mathrm{~min}$ & $55^{\circ} \mathrm{C}, 30 \mathrm{~s}$ & $72^{\circ} \mathrm{C}, 30 \mathrm{~s}$ & \\
32 & & & $72^{\circ} \mathrm{C}, 7 \mathrm{~min}$ & \\
33 & & & $4{ }^{\circ} \mathrm{C}$
\end{tabular}

77 Run a 5- $\mu$ l aliquot of the PCR product on a $1 \%$ (wt/vol) agarose gel. A PCR product of 201 bp in length indicates the presence of genomically integrated SB transposons. An example result is shown in Fig. 7A.

Identification of individual transgene integrations by ligation-mediated PCR (LMPCR) TIMING 1-2 weeks 
78 Digest $1 \mu \mathrm{g}$ of genomic DNA isolated from F0 animals with Bfal, and in a separate reaction 1 $\mu \mathrm{g}$ with DpnII (Fig. 7B), in $50 \mu \mathrm{l}$ final volumes. Include a negative control sample (genomic DNA isolated from a non-transgenic animal) as well. Follow the instructions of the enzyme supplier. To reach complete digestion, incubate the reaction for 3 hours at $37^{\circ} \mathrm{C}$.

CRITICAL STEP Always use high quality genomic DNA as template for PCR. Good quality genomic DNA runs on an agarose gel as a dominant, high molecular weight band (Fig. 7C).

79 Add $50 \mu \mathrm{l}$ phenol/chloroform/isoamyl alcohol to each tube.

80 Vortex for $10 \mathrm{~s}$ and leave on the bench for 2 min. Repeat this step 3 times.

81 Centrifuge the samples at $12000 \times g$ for 5 min at room temperature.

82 Transfer the top layer $(-50 \mu \mathrm{l})$ to a new $1.5 \mathrm{~mL}$ tube and add $5 \mu \mathrm{l}(1 / 10$ volume) of sodium acetate and $125 \mu \mathrm{l}$ (2.5 volumes) of ethanol, shake well and let the digested DNA precipitate for 30 min at $-20^{\circ} \mathrm{C}$.

83 Spin down at $12000 \times g$ for $15 \min$ at $4{ }^{\circ} \mathrm{C}$, discard the supernatant.

CRITICAL STEP The pellet is barely visible. To avoid loss of DNA, remove the liquid using a $200 \mu \mathrm{l}$ pipette tip by touching only the wall of the tube that faced the inner side of the rotor.

84 Wash the pellet in cold $70 \%$ (vol/vol) ethanol. Keep the ethanol on the pellet for $10 \mathrm{~min}$.

85 Spin down at $12000 \times \mathrm{g}$ for $15 \mathrm{~min}$ at $4{ }^{\circ} \mathrm{C}$, discard the supernatant.

CRITICAL STEP The pellet is barely visible. To avoid loss of DNA remove the liquid using a $200 \mu \mathrm{l}$ pipette tip by touching only the wall of the tube that faced the inner side of the rotor.

86 Air-dry the pellet for 5-10 minutes and resuspend it in $20 \mu$ l sterile Milli-Q water.

87 Measure the concentration of the digested DNA using a NanoDrop® spectrophotometer. The typical yield is between $30-50 \mathrm{ng} / \mu \mathrm{l}$.

88 To check digestion run 200 ng of each sample on a $1 \%$ (wt/vol) agarose gel. The digested samples should run as a smear centered between 0.5-1 kb in size (Fig. 7D).

Pause Point The digested genomic DNA samples can be stored at $-20^{\circ} \mathrm{C}$ for up to 1 year. 
89 Prepare the double-stranded linkers by mixing the Linker(+) oligo with the Linker(-)Bfal or with the Linker(-)Dpnll oligo (Table 1) in separate tubes at a final concentration of $10 \mathrm{pmol} / \mu \mathrm{l}$ each in $100 \mu \mathrm{l}$ TE buffer containing $50 \mathrm{mM} \mathrm{NaCl}$.

90 Place the tubes containing the oligonucleotide solutions into a boiling water bath for 2 min, switch off heating and leave the tubes in the bath overnight to allow a slow cool down and hybridization of the two single-stranded oligonucleotides to form the double-stranded linker.

Pause Point The annealed double-stranded oligonucleotides can be stored at $-20^{\circ} \mathrm{C}$ for up to 1 year.

91 Ligate the Bfal linkers and the Dpnll linkers to the corresponding Bfal- and DpnII-digested genomic DNA samples, respectively (Fig. 7B). Set up the ligation reaction containing the components below, and incubate overnight at $16^{\circ} \mathrm{C}$.

\begin{tabular}{|c|c|c|}
\hline Component & Amount per reaction & Final \\
\hline Ligase buffer (10x) & $5 \mu l$ & $1 \mathrm{x}$ \\
\hline Bfal- or Dpnll-digested genomic DNA & $X \mu l$ & $150 \mathrm{ng}$ \\
\hline Annealed Bfal or Dpnll linker (10 pmol/ $\mu \mathrm{l})$ & $2 \mu l$ & 20 pmol \\
\hline T4 DNA Ligase & $3 \mu l$ & $18 U$ \\
\hline $\mathrm{H}_{2} \mathrm{O}$ & $X \mu l$ & to final volume of $50 \mu \mathrm{l}$ \\
\hline
\end{tabular}

92 Set up the $1^{\text {st }} \mathrm{PCR}$ in a $50 \mu \mathrm{l}$ reaction volume containing the components below:

\begin{tabular}{lll}
\hline Component & Amount per reaction & Final \\
\hline $\mathrm{PCR}$ buffer $(10 \mathrm{x})$ & $5 \mu \mathrm{l}$ & $1 \mathrm{x}$ \\
$\mathrm{MgCl}_{2}(25 \mathrm{mM})$ & $3 \mu \mathrm{l}$ & $1.5 \mathrm{mM}$ \\
$\mathrm{dNTP}(10 \mathrm{mM})$ & $1 \mu \mathrm{l}$ & $0.2 \mathrm{mM}$ \\
Linker Primer $(10 \mathrm{pmol} / \mathrm{\mu l})(\mathrm{Table} 1)$ & $1 \mu \mathrm{l}$ & $10 \mathrm{pmol}$ \\
Primer Tbal rev3s $(10 \mathrm{pmol} / \mu \mathrm{l})($ Table 1$)$ & $1 \mu \mathrm{l}$ & $10 \mathrm{pmol}$ \\
Ligated DNA (Step 91) & $2 \mu \mathrm{l}$ & - \\
Taq DNA polymerase & $0.5 \mu \mathrm{l}$ & $2.5 \mathrm{U}$ \\
$\mathrm{H}_{2} \mathrm{O}$ & $36.5 \mu \mathrm{l}$ & - \\
\hline
\end{tabular}


93 Run the $1^{\text {st }} \mathrm{PCR}$ reaction using the following conditions:

\begin{tabular}{l|c|c|c|c} 
Cycle number & Denature & Anneal & Extend & Hold \\
\hline 1 & $96{ }^{\circ} \mathrm{C}, 2 \mathrm{~min}$ & & \\
$2-11$ & $92^{\circ} \mathrm{C}, 40 \mathrm{~s}$ & $60^{\circ} \mathrm{C}-1^{\circ} \mathrm{C} /$ cycle, $40 \mathrm{~s}$ & $72^{\circ} \mathrm{C}, 2 \mathrm{~min}$ & \\
$12-36$ & $92^{\circ} \mathrm{C}, 40 \mathrm{~s}$ & $50^{\circ} \mathrm{C}, 40 \mathrm{~s}$ & $72^{\circ} \mathrm{C}, 1 \mathrm{~min}$ & \\
37 & & & $72{ }^{\circ} \mathrm{C}, 10 \mathrm{~min}$ & \\
38 & & & & $4{ }^{\circ} \mathrm{C}$
\end{tabular}

94 Set up the $2^{\text {nd }} \mathrm{PCR}$ in a $50 \mu \mathrm{l}$ reaction volume containing the components below:

\begin{tabular}{|c|c|c|}
\hline Component & Amount per reaction & Final \\
\hline PCR buffer $(10 x)$ & $5 \mu \mathrm{l}$ & $1 x$ \\
\hline $\mathrm{MgCl}_{2}(25 \mathrm{mM})$ & $3 \mu \mathrm{l}$ & $1.5 \mathrm{mM}$ \\
\hline dNTP (10 mM) & $1 \mu \mathrm{l}$ & $0.2 \mathrm{mM}$ \\
\hline Nested Primer (10 pmol/ $\mu \mathrm{l})$ (Table 1) & $1 \mu l$ & $10 \mathrm{pmol}$ \\
\hline 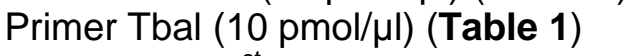 & $1 \mu l$ & $10 \mathrm{pmol}$ \\
\hline $100 x$ diluted $1^{\text {st }}$ PCR sample & $1 \mu l$ & - \\
\hline Taq DNA polymerase & $0.5 \mu \mathrm{l}$ & $2.5 U$ \\
\hline $\mathrm{H}_{2} \mathrm{O}$ & $37.5 \mu \mathrm{l}$ & - \\
\hline
\end{tabular}

95 Run the $2^{\text {nd }}$ PCR reaction using the following conditions:

\begin{tabular}{l|l|l|c|c} 
Cycle number & Denature & \multicolumn{1}{|c|}{ Anneal } & Extend & Hold \\
\hline 1 & $96^{\circ} \mathrm{C}, 2 \mathrm{~min}$ & & \\
$2-7$ & $92^{\circ} \mathrm{C}, 40 \mathrm{~s}$ & $66^{\circ} \mathrm{C}-1^{\circ} \mathrm{C} /$ cycle, $40 \mathrm{~s}$ & $72^{\circ} \mathrm{C}, 1 \mathrm{~min}$ & \\
$8-21$ & $92^{\circ} \mathrm{C}, 40 \mathrm{~s}$ & $59^{\circ} \mathrm{C}, 40 \mathrm{~s}$ & $72^{\circ} \mathrm{C}, 1 \mathrm{~min}$ & \\
22 & & & $72^{\circ} \mathrm{C}, 10 \mathrm{~min}$ & \\
23 & & & & \\
& & & &
\end{tabular}

96 Run a $10-\mu \mathrm{l}$ aliquot of the PCR product on a $1 \%(w t / v o l)$ agarose gel. An example result is shown in Fig. 7E. Each band represents a transposon (transgene) genomic integration.

\section{? TROUBLESHOOTING}


97 If strong, distinct bands are visible, isolate them from the gel using the QIAquick Gel

Extraction Kit according to the manufacturer's instructions, and sequence them. Multiple bands often represent multiple integrations and lower intensity bands may represent mosaic integrations - all of which need to be isolated from the gel, subcloned and sequenced.

98 Map the insertion sites by a BLAT or BLAST search of the DNA sequence directly flanking the transposon, at the UCSC Genome Bioinformatics website (http://genome.ucsc.edu/cgibin/hgBlat) or at the NCBI website (http://blast.ncbi.nlm.nih.gov/Blast.cgi). One should be able to identify the TA target dinucleotides immediately flanking the ITR in the genomic sequence, and the Bfal and/or Dpnll recognition sites where the LMPCR linkers were ligated. The PCR amplifications applied in parallel on the Bfal- and DpnII-digested DNA methods help the user to recover all integrations.

\section{Tracking individual transgene integrations by locus-specific PCR $\square$ TIMING 1 week}

99 Design primers matching the integration loci mapped in the founder mice (step 98). Avoid designing primers that would bind to repetitive elements and thus amplify non-specific PCR products. The BLAT search at the UCSC Genome Bioinformatics website directly provides a RepeatMasker annotation of the genomic loci where the SB transposons have integrated. When using BLAST at the NCBI website select "map viewer" for a given BLAST hit, then select "maps \& options" and choose "repeats" to see the RepeatMasker annotation. After identification of a genomic region free of repetitive sequences in the neighborhood of the SB ITR, design the locus-specific primer so that its $T_{m}$ is between $55-60{ }^{\circ} \mathrm{C}$ and its length is between 20-25 nt long. Run a BLAT or BLAST search with the new primer sequences to make sure that they do not bind to other genomic locations. In addition, general rules for PCR primer design can be found for example at http://www.premierbiosoft.com/tech_notes/PCR_Primer_Design.html.

100 Perfom the locus-specific PCR with the primer designed in Step 99 and primer Tbal (Table 1) to trace specific transgene integrations by the presence or absence of an amplified 
product. To maximize specificity of primer annealing to the genomic target, the use of touchdown PCR is recommended consisting of 5-10 touchdown cycles stepwise decreasing the annealing temperature by $1{ }^{\circ} \mathrm{C}$ per cycle down to the final annealing temperature, at about $2{ }^{\circ} \mathrm{C}$ below the $\mathrm{T}_{\mathrm{m}}$ of the lower $\mathrm{T}_{\mathrm{m}}$ primer, and 25 additional standard cycles. Fig. 8 shows an example of locus-specific PCR test of a rat founder and its F1 descendants.

\section{? TROUBLESHOOTING}

Troubleshooting advice can be found in Table 2.

\section{[CE: Table 1 is in the bottom of the file.]}

Table 2| Troubleshooting table.

\begin{tabular}{|c|c|c|c|}
\hline Step & Problem & Possible reason & Possible solution \\
\hline Step 22 & $\begin{array}{l}\text { Smear is detected in } \\
\text { the size range lower } \\
\text { than } 800 \mathrm{bp} \text {. } \\
\text { More than two } \\
\text { bands are detected. }\end{array}$ & $\begin{array}{l}\text { RNase contamination occurred } \\
\text { during or after in vitro mRNA } \\
\text { synthesis. } \\
\text { Different length products of the in } \\
\text { vitro mRNA synthesis } \\
\text { The mRNA runs aberrantly due } \\
\text { to the formations of secondary } \\
\text { structures }\end{array}$ & $\begin{array}{l}\text { Change solutions and maintain } \\
\text { RNase-free conditions. } \\
\text { Consult the troubleshooting } \\
\text { instructions of the mMessage } \\
\text { mMachine }{ }^{\circledR} \text { T7 kit. }\end{array}$ \\
\hline Steps 27,30 & $\begin{array}{l}\text { Small numbers of } \\
\text { ova or unfertilized } \\
\text { oocytes despite } \\
\text { superovulation of } \\
\text { the donors. }\end{array}$ & $\begin{array}{l}\text { Hormone treatment failed or is } \\
\text { suboptimal. } \\
\text { Age of animals is suboptimal. } \\
\text { External disturbances to the } \\
\text { mice during preparation of ova. }\end{array}$ & $\begin{array}{l}\text { Prepare fresh hormone solutions } \\
\text { and store up to } 4 \text { weeks at - } \\
20^{\circ} \mathrm{C} \text {, if necessary up to } 6 \\
\text { months at }-80{ }^{\circ} \mathrm{C} \text { until use. } \\
\text { Use females and males of } \\
\text { appropriate age as described. } \\
\text { Use experienced males. } \\
\text { However, males of the inbred } \\
\text { strain C57BL/6 are often bad } \\
\text { breeders if their age exceeds } 6 \\
\text { months. } \\
\text { Avoid cage changing or other } \\
\text { activities during superovulation } \\
\text { and mating of donors. }\end{array}$ \\
\hline Step 34 & $\begin{array}{l}\text { No visible swelling } \\
\text { of the injected } \\
\text { pronucleus. }\end{array}$ & Injection capillaries clogged. & $\begin{array}{l}\text { Remove remaining particles from } \\
\text { the injection mixture by } \\
\text { centrifuging for } 10 \text { min at } 16.1 x \\
g \text { at } 4{ }^{\circ} \mathrm{C} \text {, and carefully transfer }\end{array}$ \\
\hline
\end{tabular}




\begin{tabular}{|c|c|c|c|}
\hline & & & $\begin{array}{l}\text { the upper part of the injection } \\
\text { solution to a fresh } 1.5 \mathrm{~mL} \text { tube } \\
\text { (Steps } 25-26 \text { ). } \\
\text { Pull new, clean injection } \\
\text { capillaries. }\end{array}$ \\
\hline Steps 35,62 & $\begin{array}{l}\text { High rate (over } 20 \\
\% \text { ) of lysed ova } \\
\text { immediately or } \\
\text { shortly after DNA } \\
\text { microinjection. }\end{array}$ & $\begin{array}{l}\text { Shrinking due to suboptimal } \\
\text { culture conditions during } \\
\text { microinjection, excessive } \\
\text { injection volume, or poor quality } \\
\text { of injection capillaries. }\end{array}$ & $\begin{array}{l}\text { Optimize culture conditions } \\
\text { during the injection procedure, } \\
\text { reduce the injection pressure to } \\
\text { enable better control of injection } \\
\text { volume, or change the injection } \\
\text { capillaries. }\end{array}$ \\
\hline Steps 39,74 & $\begin{array}{l}\text { Surrogate mothers } \\
\text { do not become } \\
\text { pregnant. }\end{array}$ & $\begin{array}{l}\text { Surrogate mothers were } \\
\text { stimulated with vasectomized } \\
\text { males in an inappropriate phase } \\
\text { of the estrus cycle. } \\
\text { Induction of a pregnancy block } \\
\text { by exposure to the pheremones } \\
\text { of a foreign male (Bruce effect). } \\
\text { Failure/inefficient establishing of } \\
\text { surrogate mothers. }\end{array}$ & $\begin{array}{l}\text { The presence of a vaginal plug } \\
\text { does not ensure } \\
\text { psuedopregnancy. Therefore, } \\
\text { pseudopregnancy must be } \\
\text { confirmed by inspection of the } \\
\text { ampulla, the ovaries and ovarian } \\
\text { bursa (corpus hemorragicum and } \\
\text { blood vessels, respectively) } \\
\text { during embryo transfer. } \\
\text { Recipients can also be pre- } \\
\text { selected by vaginal cytology to } \\
\text { select females in proestrus for } \\
\text { mating. } \\
\text { Avoid exposing recipients to } \\
\text { foreign male phermones during } \\
\text { early pregnancy. } \\
\text { Confirm pseudopregnancy of } \\
\text { plugged surrogate mothers by } \\
\text { the swollen ampulla. } \\
\text { Avoid exposure of surrogate } \\
\text { mothers to olfactory cues of } \\
\text { foreign males. }\end{array}$ \\
\hline Steps 39,74 & Small litters. & $\begin{array}{l}\text { Residual harmful chemicals } \\
\text { remaining in the microinjection } \\
\text { mixture. }\end{array}$ & $\begin{array}{l}\text { Carefully washing the } \\
\text { precipitated plasmid DNA and } \\
\text { mRNA with } 70 \% \text { ethanol (Steps } \\
9 \text { and 18) is important for the } \\
\text { removal of residual } \\
\text { phenol/chloroform. } \\
\text { DEPC is not tolerated by the } \\
\text { ova. Consequently, RNase-free } \\
\text { solutions that come in contact } \\
\text { with the injected material should } \\
\text { be purified by filtration. } \\
\text { Prepare new batches of culture } \\
\text { media. Test media and oil for } \\
\text { toxicity by overnight culture with } \\
\text { ova. }\end{array}$ \\
\hline Step 65 & $\begin{array}{l}\text { High rate (over } 20 \\
\% \text { ) of uncleaved ova } \\
\text { after in vitro } \\
\text { culturing of injected }\end{array}$ & $\begin{array}{l}\text { Suboptimal in vitro culture } \\
\text { conditions, suboptimal injection } \\
\text { procedure, and damage of ova } \\
\text { during manipulation in vitro. }\end{array}$ & $\begin{array}{l}\text { Lowering the amount of } \\
\text { DNA/mRNA mix down to } 50 \% \text { of } \\
\text { the original concentration in the } \\
\text { injection solution (Step } 26 \text { ) might }\end{array}$ \\
\hline
\end{tabular}




\begin{tabular}{|c|c|c|c|}
\hline & ova. & & $\begin{array}{l}\text { remarkably increase the number } \\
\text { of } 2 \text {-cell embryos suitable for } \\
\text { transfer into the foster-mothers. }\end{array}$ \\
\hline Steps 77, 96 & $\begin{array}{l}\text { Low frequency of } \\
\text { transgenic founders } \\
\text { per litter. }\end{array}$ & $\begin{array}{l}\text { Integrity of transposase mRNA } \\
\text { compromised } \\
\text { Larger transgenes may cause a } \\
\text { drop of transgenesis rates. } \\
\text { Transgene detection problems, } \\
\text { e. g., because the genomic DNA } \\
\text { template used in the PCR tests } \\
\text { is degraded. }\end{array}$ & $\begin{array}{l}\text { Always use RNase-free } \\
\text { laboratory plastic and glassware } \\
\text { and wear gloves while handling } \\
\text { reagents and samples to prevent } \\
\text { RNase contamination. } \\
\text { Do not re-use injection mixture } \\
\text { after microinjection due to the } \\
\text { increased risk of RNase } \\
\text { contamination. } \\
\text { Increasing the amount of } \\
\text { transposon (transgene) donor } \\
\text { plasmid in the final injection } \\
\text { mixture (preferably not over } 2 \\
\text { ng/ul; Step 26) may help to } \\
\text { increase the efficiency in case of } \\
\text { larger transgenes. } \\
\text { Always use high-quality genomic } \\
\text { DNA for PCR, as defined in Step } \\
78 . \\
\text { Include a positive control (DNA } \\
\text { from an established transgenic } \\
\text { animal) in the PCR tests. }\end{array}$ \\
\hline
\end{tabular}

\section{TIMING}

\section{Praparation of Sleeping Beauty transposon components for microinjection}

Steps 1-13, Preparation of RNase-free transposon (ITR-flanked transgene) donor plasmid: 2-4 h

Steps 14-24, Preparation of the transposase mRNA: 10-14 h

Steps 25-26, Preparation of the microinjection mixture: $1 \mathrm{~h}$

\section{Transgenesis with Sleeping Beauty in mice}

Step 27-28, Preparation of the ovum donors: 3 days

Steps 29-31, Isolation of ova: 1 hour

Steps 32-35, Microinjection of ova: 2-3 hours

Step 36, Preparation of surrogate mothers: 1-3 days

Steps 37-39, Embryo transfer: 2 hours

\section{Transgenesis with Sleeping Beauty in rats}


Steps 40-44, Preparation of vasectomized males: 14 days

Steps 45-47, Superovulation of female donors: 3 days

Steps 48-55, Recovery and manipulation of ova: 1 hour per 8 superovulated donors

Steps 56-62, Pronuclear injection: 1-3 hours per 100-200 ova

Steps 63-65, In vitro culture of injected ova: 15-20 hours

Steps 66-67, Preparation of pseudopregnant recipients (surrogate mothers): 1 day

Steps 68-74, Embryo transfer into recipient foster mothers: 1 hour per 8 recipient foster mothers

\section{Genotyping of transgenic animals}

Steps 75-77, Confirming transposon insertions by PCR: 2.5 hours

Steps 78-98, Identification of individual transgene integration events by LMPCR: 1-2 weeks

Steps 99-100, Tracking individual transgene integrations by locus-specific PCR: 1 week

\section{ANTICIPATED RESULTS}

The frequency of transgenic founders using SB transposon-mediated transgenesis is expected to be in the range of 50-70 \% of live births in mice and 14-65 \% in rats (Fig. 7). We found that for efficient transposition of a transposon of about $3 \mathrm{~kb}$ in length, using the optimized concentration of $0.4 \mathrm{ng} / \mu \mathrm{l}$ of plasmid and $5 \mathrm{ng} / \mu \mathrm{l}$ of SB100X mRNA will result in a high frequency of founders with single integration sites. Depending on the size of the transposon it may be necessary to modify these concentrations. The number of independent integration sites per genome (Fig. 8) can be more efficiently controlled by modifying the concentration of injected transposon donor plasmid than by modifying the concentration of transposase mRNA ${ }^{61}$. Lowering the concentration of transposon plasmid should lead to a decrease in multiple integrations. Transposon insertions are expected to be randomly distributed in the genome, with most transgenes located in intergenic regions. Nearly all founders produced by SB100X transposition are expected to transmit the transgene to the next generation. Although some differences in transgene expression levels and patterns between the founder lines are expected, there is no significant transgene silencing in the F0 and F1 generations. 


\section{Acknowledgements}

Research of M.P. and V.L. was supported by grant TA02010013 from Technological Agency of the Czech Republic (TACR) and grants LH12061 and LL1204 (in the ERC CZ program) from the Ministry of Education, Youth and Sports of the Czech Republic. Financial support by grants of the Deutsche Forschungsgemeinschaft (KU 1586/2-1 and IV 21/6-1) to W.A.K. and Z.IV., and from the Austrian Genome Research Programme GEN-AU II and III (Austromouse) to T.R. is gratefully acknowledged.

\section{Competing financial interests statement}

The authors declare that they have no competing financial interests.

\section{Author contributions statement}

Design of study: T. Rülicke, M. Pravenec, A. Geurts, Z. Ivics, Z. Izsvak, L. Mates

Performance of experiments: L. Mates, T.Y. Yau, S. Bashir, V. Zidek, V. Landa, A. Geurts

Evaluation of data: W.A. Kues, Z. Ivics, W. Garrels, O.I. Hoffmann, L. Hiripi, Z. Bosze

Writing of manuscript: Z. Ivics, T. Rülicke, M. Pravenec, L. Mates, V. Landa, Z. Izsvak

\section{REFERENCES}

1. Hrabe de Angelis, M.H. et al. Genome-wide, large-scale production of mutant mice by ENU mutagenesis. Nat Genet 25, $444-7$ (2000).

2. van Boxtel, R., Gould, M.N., Cuppen, E. \& Smits, B.M. ENU mutagenesis to generate genetically modified rat models. Methods Mol Biol 597, 151-67 (2010).

3. Nolan, P.M. et al. A systematic, genome-wide, phenotype-driven mutagenesis programme for gene function studies in the mouse. Nat Genet 25, 440-3 (2000).

4. Skarnes, W.C. et al. A public gene trap resource for mouse functional genomics. Nat Genet 36, 543-4 (2004).

5. Skarnes, W.C. et al. A conditional knockout resource for the genome-wide study of mouse gene function. Nature 474, 337-42 (2011).

6. Wilkinson, P. et al. EMMA--mouse mutant resources for the international scientific community. Nucleic Acids Res 38, D570-6 (2010). 
7. Gibbs, R.A. et al. Genome sequence of the Brown Norway rat yields insights into mammalian evolution. Nature 428, 493-521 (2004).

8. Waterston, R.H. et al. Initial sequencing and comparative analysis of the mouse genome. Nature 420, 520-62 (2002).

9. Consortium, I.H.G.S. Finishing the euchromatic sequence of the human genome. Nature 431, 931-45 (2004).

10. Richter, C.P. The effects of domestication and selection on the behavior of the Norway rat. $J$ Natl Cancer Inst 15, 727-38 (1954).

11. Evans, M.J. \& Kaufman, M.H. Establishment in culture of pluripotential cells from mouse embryos. Nature 292, 154-6 (1981).

12. Gossler, A., Joyner, A.L., Rossant, J. \& Skarnes, W.C. Mouse embryonic stem cells and reporter constructs to detect developmentally regulated genes. Science 244, 463-5 (1989).

13. Li, P. et al. Germline competent embryonic stem cells derived from rat blastocysts. Cell 135, 1299-310 (2008).

14. Mansour, S.L., Thomas, K.R. \& Capecchi, M.R. Disruption of the proto-oncogene int-2 in mouse embryo-derived stem cells: a general strategy for targeting mutations to nonselectable genes. Nature 336, 348-52 (1988).

15. Martin, G.R. Isolation of a pluripotent cell line from early mouse embryos cultured in medium conditioned by teratocarcinoma stem cells. Proc Natl Acad Sci U S A 78, 7634-8 (1981).

16. Buehr, M. et al. Capture of authentic embryonic stem cells from rat blastocysts. Cell 135, 1287-98 (2008).

17. Tong, C., Huang, G., Ashton, C., Li, P. \& Ying, Q.L. Generating gene knockout rats by homologous recombination in embryonic stem cells. Nat Protoc 6, 827-44 (2011).

18. Ying, Q.L. et al. The ground state of embryonic stem cell self-renewal. Nature 453, 519-23 (2008).

19. Tong, C., Li, P., Wu, N.L., Yan, Y. \& Ying, Q.L. Production of p53 gene knockout rats by homologous recombination in embryonic stem cells. Nature 467, 211-3 (2010).

20. Boch, J. et al. Breaking the code of DNA binding specificity of TAL-type III effectors. Science 326, 1509-12 (2009).

21. Geurts, A.M. et al. Knockout rats via embryo microinjection of zinc-finger nucleases. Science 325, 433 (2009).

22. Meyer, M., de Angelis, M.H., Wurst, W. \& Kuhn, R. Gene targeting by homologous recombination in mouse zygotes mediated by zinc-finger nucleases. Proc Natl Acad Sci U S A 107, 15022-6 (2010).

23. Moscou, M.J. \& Bogdanove, A.J. A simple cipher governs DNA recognition by TAL effectors. Science 326, 1501 (2009).

24. Shen, B. et al. Generation of gene-modified mice via Cas9/RNA-mediated gene targeting. Cell Res 23, 720-3 (2013).

25. Wang, H. et al. One-Step Generation of Mice Carrying Mutations in Multiple Genes by CRISPR/Cas-Mediated Genome Engineering. Cell 153, 910-8 (2013).

26. Zheng, S., Geghman, K., Shenoy, S. \& Li, C. Retake the center stage--new development of rat genetics. J Genet Genomics 39, 261-8 (2012).

27. Gordon, J.W. \& Ruddle, F.H. Integration and stable germ line transmission of genes injected into mouse pronuclei. Science 214, 1244-6 (1981).

28. Charreau, B., Tesson, L., Soulillou, J.P., Pourcel, C. \& Anegon, I. Transgenesis in rats: technical aspects and models. Transgenic Res 5, 223-34 (1996).

29. Mullins, J.J., Peters, J. \& Ganten, D. Fulminant hypertension in transgenic rats harbouring the mouse Ren-2 gene. Nature 344, 541-4 (1990). 
30. Gordon, J.W., Scangos, G.A., Plotkin, D.J., Barbosa, J.A. \& Ruddle, F.H. Genetic transformation of mouse embryos by microinjection of purified DNA. Proc Natl Acad Sci $U$ $S$ A 77, 7380-4 (1980).

31. Michalkiewicz, M. \& Michalkiewicz, T. Developing transgenic neuropeptide Y rats. Methods Mol Biol 153, 73-89 (2000).

32. Michalkiewicz, M., Michalkiewicz, T., Kreulen, D.L. \& McDougall, S.J. Increased blood pressure responses in neuropeptide Y transgenic rats. Am J Physiol Regul Integr Comp Physiol 281, R417-26 (2001).

33. Brinster, R.L., Chen, H.Y., Trumbauer, M.E., Yagle, M.K. \& Palmiter, R.D. Factors affecting the efficiency of introducing foreign DNA into mice by microinjecting eggs. Proc Natl Acad Sci U S A 82, 4438-42 (1985).

34. Bishop, J.O. \& Smith, P. Mechanism of chromosomal integration of microinjected DNA. Mol Biol Med 6, 283-98 (1989).

35. Cousens, C. et al. Use of PCR-based methods for selection of integrated transgenes in preimplantation embryos. Mol Reprod Dev 39, 384-91 (1994).

36. Whitelaw, C.B., Springbett, A.J., Webster, J. \& Clark, J. The majority of G0 transgenic mice are derived from mosaic embryos. Transgenic Res 2, 29-32 (1993).

37. Garrick, D., Fiering, S., Martin, D.I. \& Whitelaw, E. Repeat-induced gene silencing in mammals. Nat Genet 18, 56-9 (1998).

38. Covarrubias, L., Nishida, Y. \& Mintz, B. Early postimplantation embryo lethality due to DNA rearrangements in a transgenic mouse strain. Proc Natl Acad Sci U S A 83, 6020-4 (1986).

39. Kohrman, D.C. et al. Insertional mutation of the motor endplate disease (med) locus on mouse chromosome 15. Genomics 26, 171-7 (1995).

40. Wilkie, T.M. \& Palmiter, R.D. Analysis of the integrant in MyK-103 transgenic mice in which males fail to transmit the integrant. Mol Cell Biol 7, 1646-55 (1987).

41. Hirabayashi, M., Kato, M., Amemiya, K. \& Hochi, S. Direct comparison between ICSImediated DNA transfer and pronuclear DNA microinjection for producing transgenic rats. Exp Anim 57, 145-8 (2008).

42. Perry, A.C. et al. Mammalian transgenesis by intracytoplasmic sperm injection. Science 284, 1180-3 (1999).

43. Kato, M. et al. Production of transgenic rats by ooplasmic injection of spermatogenic cells exposed to exogenous DNA: a preliminary study. Mol Reprod Dev 69, 153-8 (2004).

44. Moreira, P.N. et al. Effect of transgene concentration, flanking matrix attachment regions, and RecA-coating on the efficiency of mouse transgenesis mediated by intracytoplasmic sperm injection. Biol Reprod 76, 336-43 (2007).

45. Ajduk, A., Yamauchi, Y. \& Ward, M.A. Sperm chromatin remodeling after intracytoplasmic sperm injection differs from that of in vitro fertilization. Biol Reprod 75, 442-51 (2006).

46. Fernandez-Gonzalez, R. et al. Long-term effects of mouse intracytoplasmic sperm injection with DNA-fragmented sperm on health and behavior of adult offspring. Biol Reprod 78, 76172 (2008).

47. Lois, C., Hong, E.J., Pease, S., Brown, E.J. \& Baltimore, D. Germline transmission and tissue-specific expression of transgenes delivered by lentiviral vectors. Science 295, 868-72 (2002).

48. Park, F. Lentiviral vectors: are they the future of animal transgenesis? Physiol Genomics 31, 159-73 (2007).

49. Michalkiewicz, M. et al. Efficient transgenic rat production by a lentiviral vector. Am $J$ Physiol Heart Circ Physiol 293, H881-94 (2007). 
50. Ivics, Z., Hackett, P.B., Plasterk, R.H. \& Izsvak, Z. Molecular reconstruction of Sleeping Beauty, a Tc1-like transposon from fish, and its transposition in human cells. Cell 91, 501-10 (1997).

51. Ivics, Z. et al. Transposon-mediated genome manipulation in vertebrates. Nat Methods 6, 415-22 (2009).

52. Zayed, H., Izsvak, Z., Walisko, O. \& Ivics, Z. Development of hyperactive sleeping beauty transposon vectors by mutational analysis. Mol Ther 9, 292-304 (2004).

53. Rostovskaya, M. et al. Transposon-mediated BAC transgenesis in human ES cells. Nucleic Acids Res 40, e150 (2012).

54. Voigt, K. et al. Retargeting sleeping beauty transposon insertions by engineered zinc finger DNA-binding domains. Mol Ther 20, 1852-62 (2012).

55. Moldt, B. et al. Comparative genomic integration profiling of Sleeping Beauty transposons mobilized with high efficacy from integrase-defective lentiviral vectors in primary human cells. Mol Ther 19, 1499-510 (2011).

56. Grabundzija, I. et al. Comparative analysis of transposable element vector systems in human cells. Mol Ther 18, 1200-9 (2010).

57. Ammar, I. et al. Retargeting transposon insertions by the adeno-associated virus Rep protein. Nucleic Acids Res 40, 6693-712 (2012).

58. Ivics, Z. \& Izsvak, Z. The expanding universe of transposon technologies for gene and cell engineering. Mob DNA 1, 25 (2010).

59. Ammar, I., Izsvak, Z. \& Ivics, Z. The Sleeping Beauty transposon toolbox. Methods Mol Biol 859, 229-40 (2012).

60. Mates, L. et al. Molecular evolution of a novel hyperactive Sleeping Beauty transposase enables robust stable gene transfer in vertebrates. Nat Genet 41, 753-61 (2009).

61. Katter, K. et al. Transposon-mediated transgenesis, transgenic rescue, and tissue-specific gene expression in rodents and rabbits. FASEB J 27, 930-41 (2013).

62. Ivics, Z. et al. Germline Transgenesis in Rabbits by Pronuclear Microinjection of Sleeping Beauty Transposons. Nature Protocols in press(2014).

[CE: references 62 and 64 are sister protocols and will be published by us along with this protocol.]

63. Garrels, W. et al. Germline transgenic pigs by Sleeping Beauty transposition in porcine zygotes and targeted integration in the pig genome. PLoS One 6, e23573 (2011).

64. Ivics, Z. et al. Germline Transgenesis in Pigs by Cytoplasmic Microinjection of Sleeping Beauty Transposons. Nature Protocols in press(2014).

65. Ellis, J. Silencing and variegation of gammaretrovirus and lentivirus vectors. Hum Gene Ther 16, 1241-6 (2005).

66. Jahner, D. et al. De novo methylation and expression of retroviral genomes during mouse embryogenesis. Nature 298, 623-8 (1982).

67. Wolf, D. \& Goff, S.P. Embryonic stem cells use ZFP809 to silence retroviral DNAs. Nature 458, 1201-4 (2009).

68. Claeys Bouuaert, C., Lipkow, K., Andrews, S.S., Liu, D. \& Chalmers, R. The autoregulation of a eukaryotic DNA transposon. Elife 2, e00668 (2013).

69. O'Malley, R.C., Alonso, J.M., Kim, C.J., Leisse, T.J. \& Ecker, J.R. An adapter ligationmediated PCR method for high-throughput mapping of T-DNA inserts in the Arabidopsis genome. Nat Protoc 2, 2910-7 (2007).

70. Ivics, Z., Izsvak, Z., Medrano, G., Chapman, K.M. \& Hamra, F.K. Sleeping Beauty transposon mutagenesis in rat spermatogonial stem cells. Nat Protoc 6, 1521-35 (2011).

71. Ro, H., Soun, K., Kim, E.J. \& Rhee, M. Novel vector systems optimized for injecting in vitro-synthesized mRNA into zebrafish embryos. Mol Cells 17, 373-6 (2004). 
72. Ittner, L.M. \& Gotz, J. Pronuclear injection for the production of transgenic mice. Nat Protoc 2, 1206-15 (2007).

73. Rulicke, T. Pronuclear microinjection of mouse zygotes. in Germ Cell Protocols (ed. Schatten, H.) 165-194 (Humana Press Inc., 2004).

74. Whitten, W.K. Modification of the oestrous cycle of the mouse by external stimuli associated with the male. J Endocrinol 13, 399-404 (1956).

75. Arras, M., Autenried, P., Rettich, A., Spaeni, D. \& Rulicke, T. Optimization of intraperitoneal injection anesthesia in mice: drugs, dosages, adverse effects, and anesthesia depth. Comp Med 51, 443-56 (2001).

76. Kolbe, T., Palme, R., Touma, C. \& Rulicke, T. Repeated use of surrogate mothers for embryo transfer in the mouse. Biol Reprod 86, 1-6 (2012).

77. Rulicke, T., Haenggli, A., Rappold, K., Moehrlen, U. \& Stallmach, T. No transuterine migration of fertilised ova after unilateral embryo transfer in mice. Reprod Fertil Dev 18, 885-91 (2006).

78. Bruce, H.M. An exteroceptive block to pregnancy in the mouse. Nature 184, 105 (1959).

79. Marashi, V. \& Rulicke, T. The Bruce effect in Norway rats. Biol Reprod 86, 1-5 (2012).

80. Mates, L. Rodent transgenesis mediated by a novel hyperactive Sleeping Beauty transposon system. Methods Mol Biol 738, 87-99 (2011). 


\section{FIGURE LEGENDS}

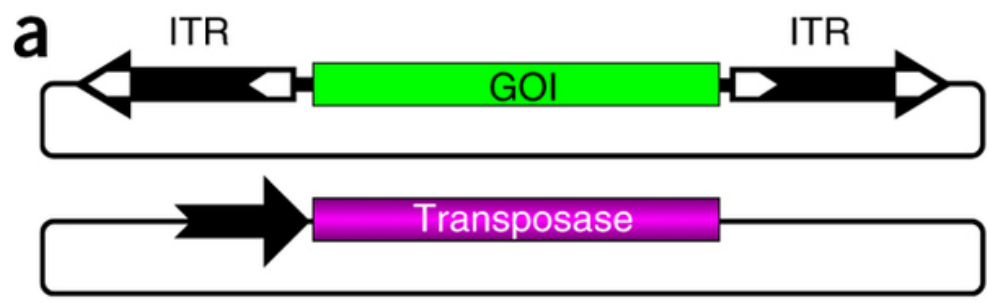

Synthetic transposase mRNA

b

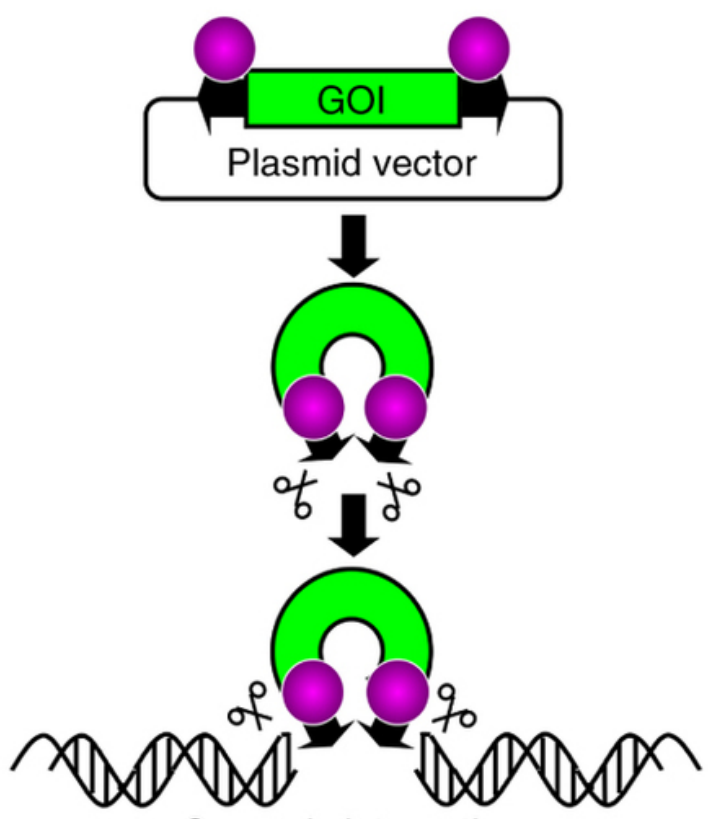

Genomic integration

Figure 1. Application of Sleeping Beauty transposons for gene delivery. (A) A bi-component transposon system for delivering transgenes in plasmids. One component contains a gene of interest (GOI) cloned between the transposon inverted terminal repeats (ITR, black arrows) encoded by a plasmid. The other component is either a transposase expression plasmid, or synthetic mRNA encoding the transposase. (B) The transposon carrying a GOI is excised from the donor plasmid and is integrated at a chromosomal site by the transposase (purple spheres). 


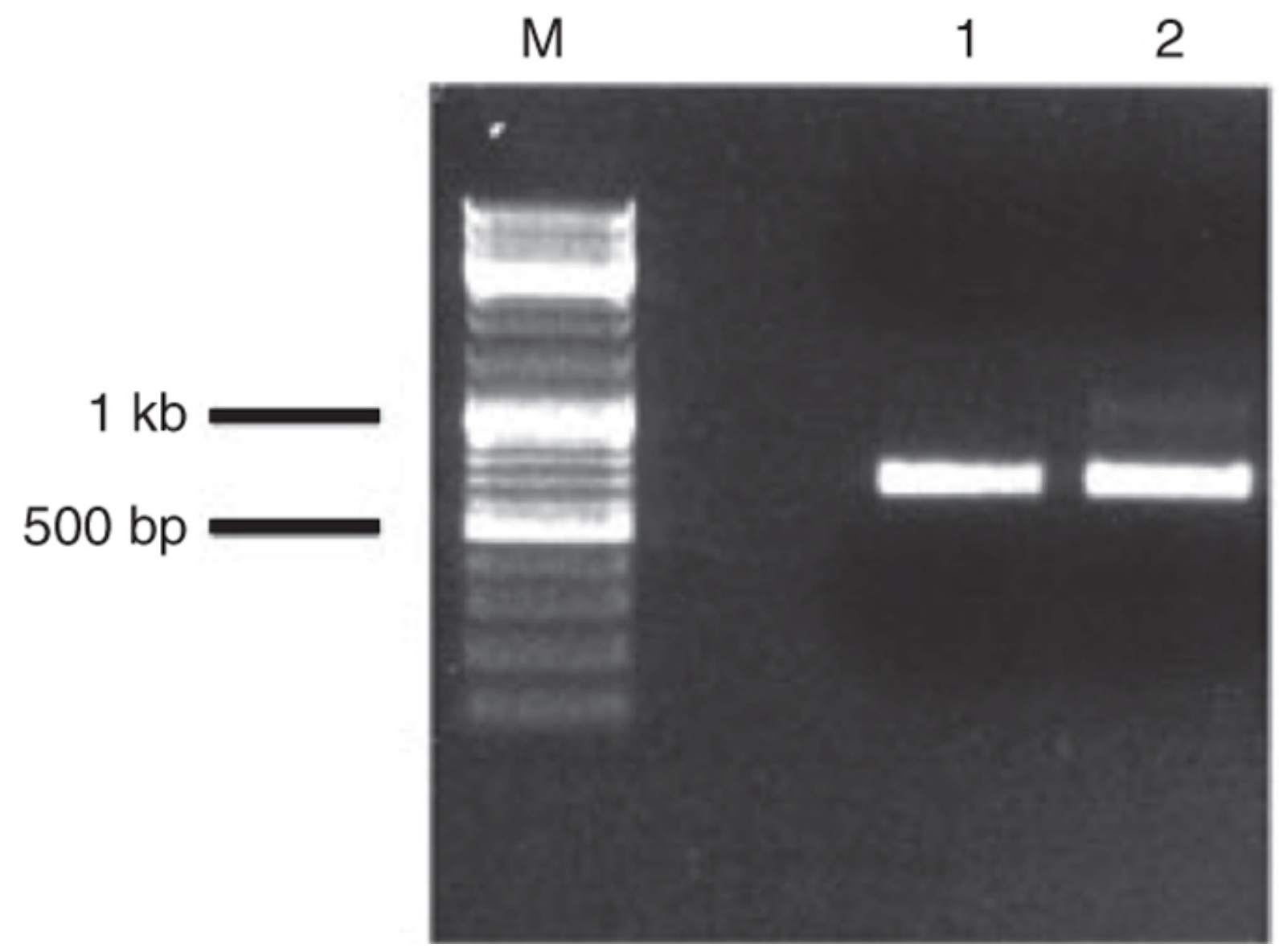

Figure 2. Result of in vitro mRNA synthesis and test of the microinjection buffer. mRNA quality can be determined by standard RNase-free agarose electrophoresis and ethidium bromide staining. Samples are run on a $1 \%$ (wt/vol) RNase-free non-denaturing agarose gel. Lanes: M) DNA size marker; 1) $1 \mu \mathrm{l}$ of in vitro synthesized mRNA; 2) $1 \mu \mathrm{l}$ of in vitro synthesized mRNA incubated $\left(1 \mathrm{~h}, 37^{\circ} \mathrm{C}\right)$ in $10 \mu \mathrm{l}$ EmbryoMax ${ }^{\circledR}$ injection buffer to detect the potential presence of RNase in the buffer (reproduced with permission from ref. ${ }^{80}$ ). Shown is a result without visible signs of mRNA degradation. 
a

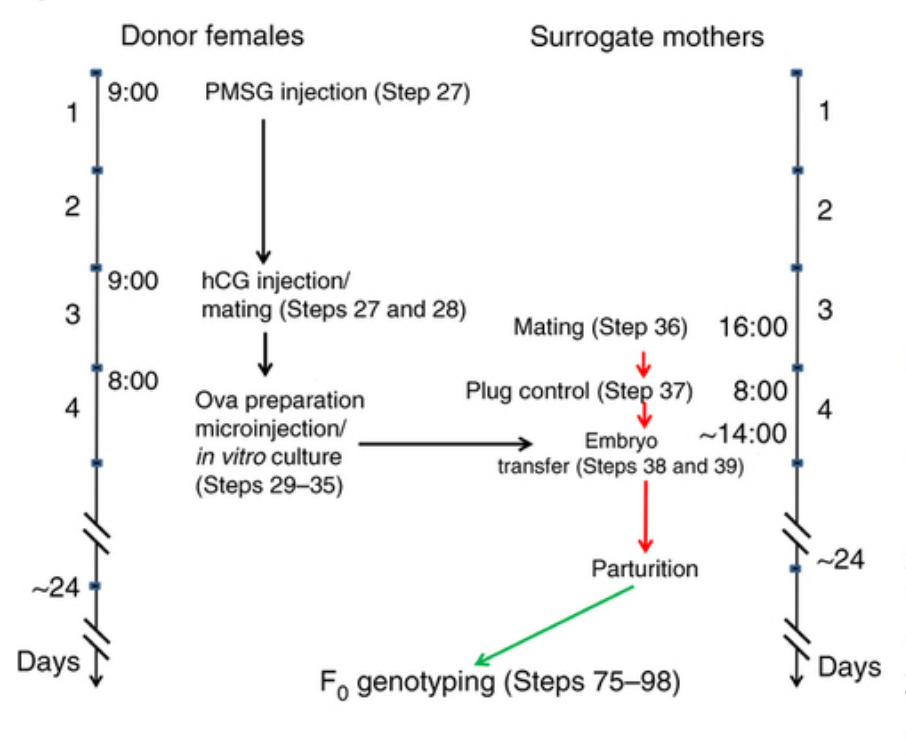

b

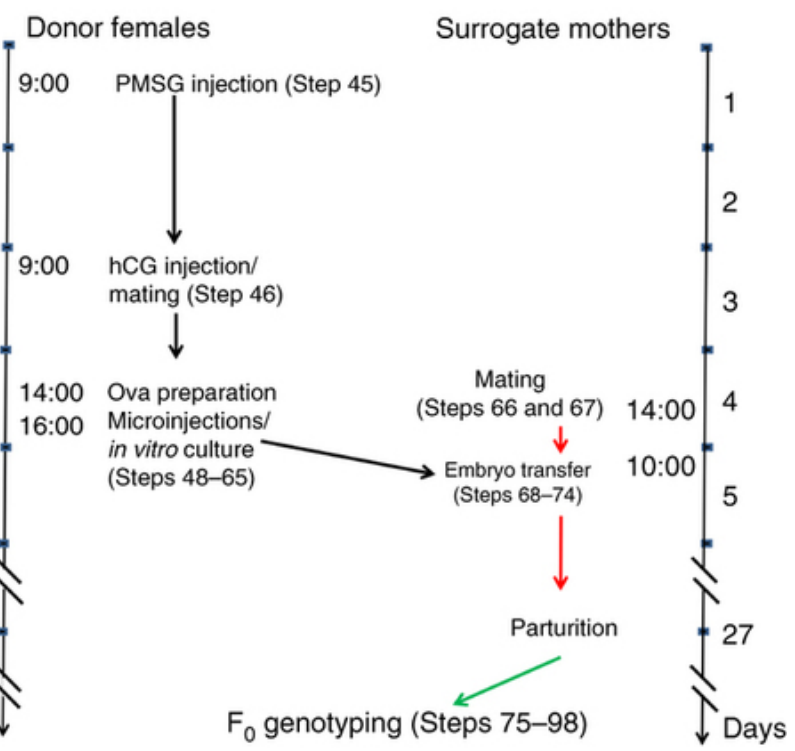

Figure 3. Timelines for animal manipulations. Timing (in days) of the important protocol steps for mice $(\mathbf{A})$ and rats $(B)$ starting from the preparation of ova donors and ending with parturition and genotyping of the F0-offspring. 


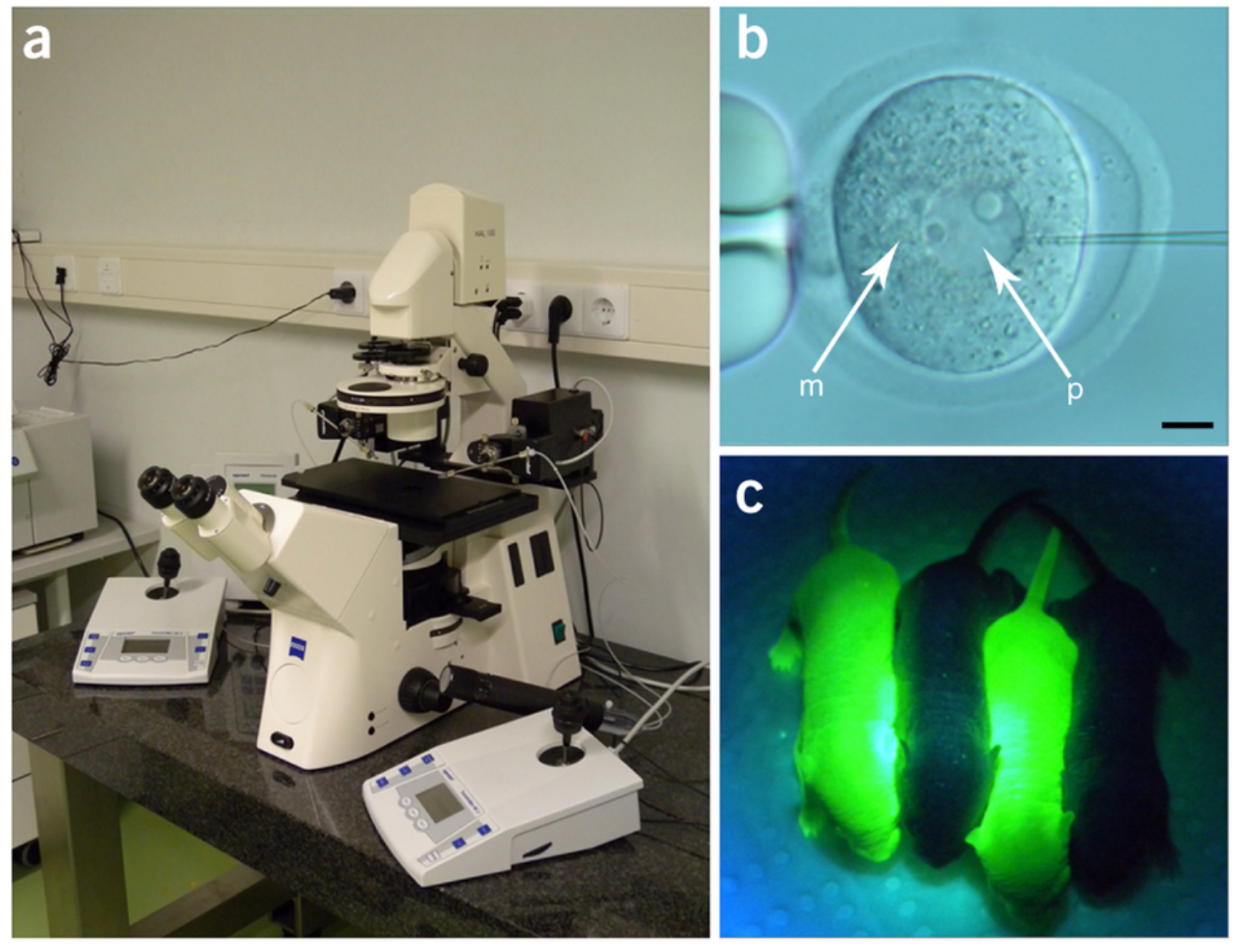

Figure 4. Overview of mouse transgenesis. (A) Inverted microscope equipped with Normarski optic (DCl), microinjectors for holding, and injection capillaries and micromanipulators on a vibration-damped microscope table. (B) Co-injection of the ITR-flanked transgene plasmid and transposase mRNA into the paternal pronucleus (p) of a mouse ovum fixed by a holding capillary. The maternal pronucleus $(\mathrm{m})$ is visible but out of focus in this picture. (C) Detecting successful transposition and transgenesis among F0 offspring, expressing the Venus fluorescent reporter gene. 

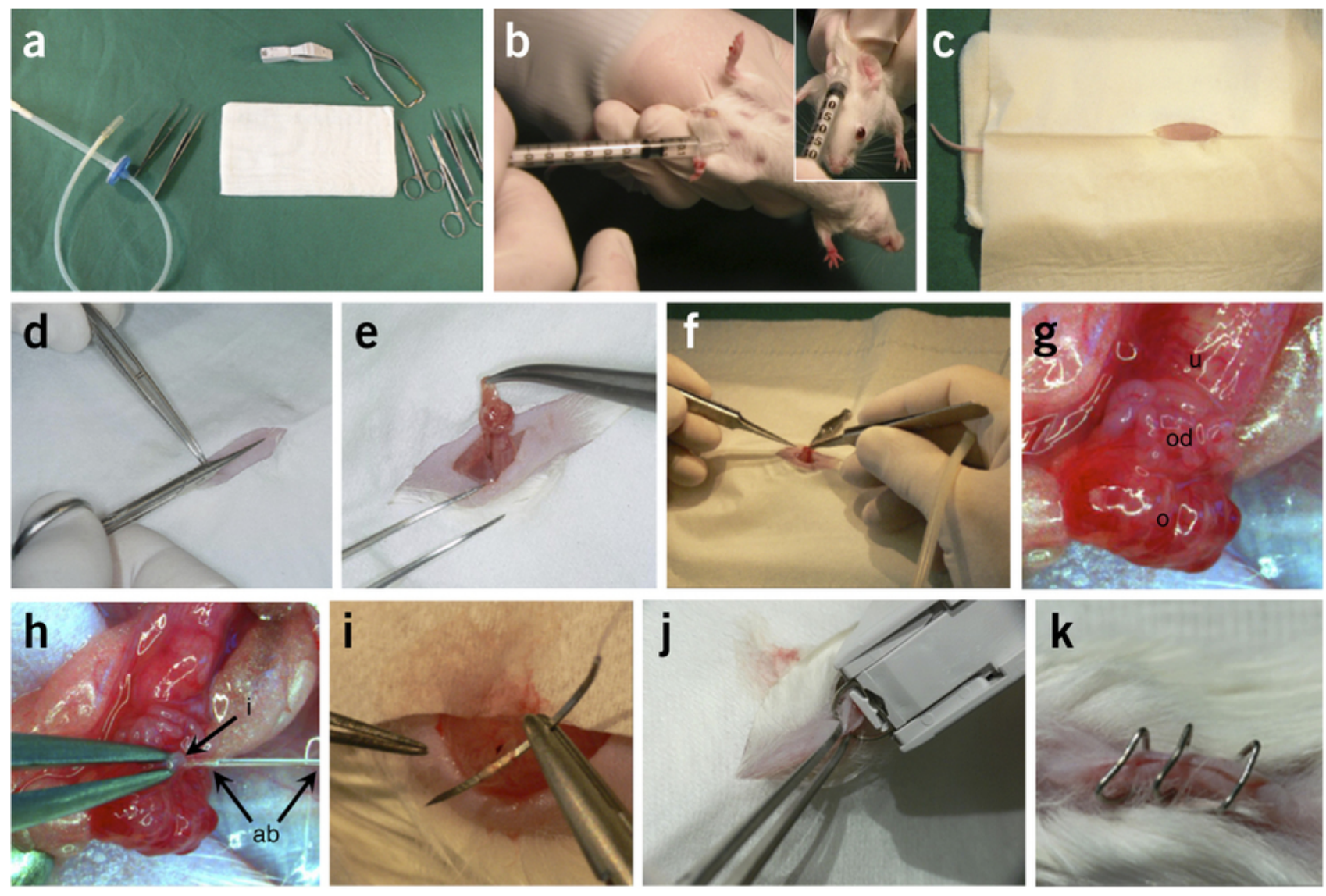

Figure 5. Equipment and steps for mouse transgenesis. (A) Specific equipment for the embryo transfer (2 watchmaker forceps, 2 curved dissecting forceps, sharp and blunt scissors, bulldog clamp, needle holder with absorbable atraumatic sutures, skin stapler, tubing with holder for the transfer capillary). (B) Intraperitonial injection of anesthetics to a pseudopregnant surrogate mother. Before she awakens from anesthesia, the mouse is treated for analgesia using a subcutaneous injection of Meloxicam (small picture). (C) The partially shaved and disinfected mouse in deep anesthesia prepared for surgery. (D) Incision of the skin about $1.5 \mathrm{~cm}$-long along the dorsal midline below the last rib allows for access to both sides of the reproductive organs. Alternatively, separate incisions can be made on each flank. (E) Incision of the abdominal wall close to the visible ovary allows for the gentle extraction of the ipsilateral ovary, oviduct and top of the uterine horn. (F) The fat pad on the ovary is used to fix the female genital tract using a bulldog clamp. To reach the infundibulum, the bursa (a thin transparent connective tissue membrane that covers the ovaries) is carefully opened with two watchmaker forceps without injuring blood vessels. (G) Embryo transfer 
is performed with a stereo microscope with about $25 x$ magnification ( $\mathrm{o}=$ ovary, od = oviduct, $\mathrm{u}=$ uterus). (H) Injected zygotes are transferred with a mouth controlled glass capillary directly via the infundibulum (i) into the oviduct. The inserted capillary is fixed with watchmaker forceps. To ensure correct transfer into the ampulla of the oviduct, the embryos in M2 medium are located between two air bubbles in the glass capillary (ab) which can be followed during the procedure. (I) After the transfer, the female genital tract is gently placed back into the abdominal cavity and the incision is closed with an abdominal suture. (J) The cut in the skin is carefully closed with suture clips. (K) Suture clips do not need to be removed because they are either rejected after wound healing or do not disturb the surrogate mother until weaning of the offspring. 


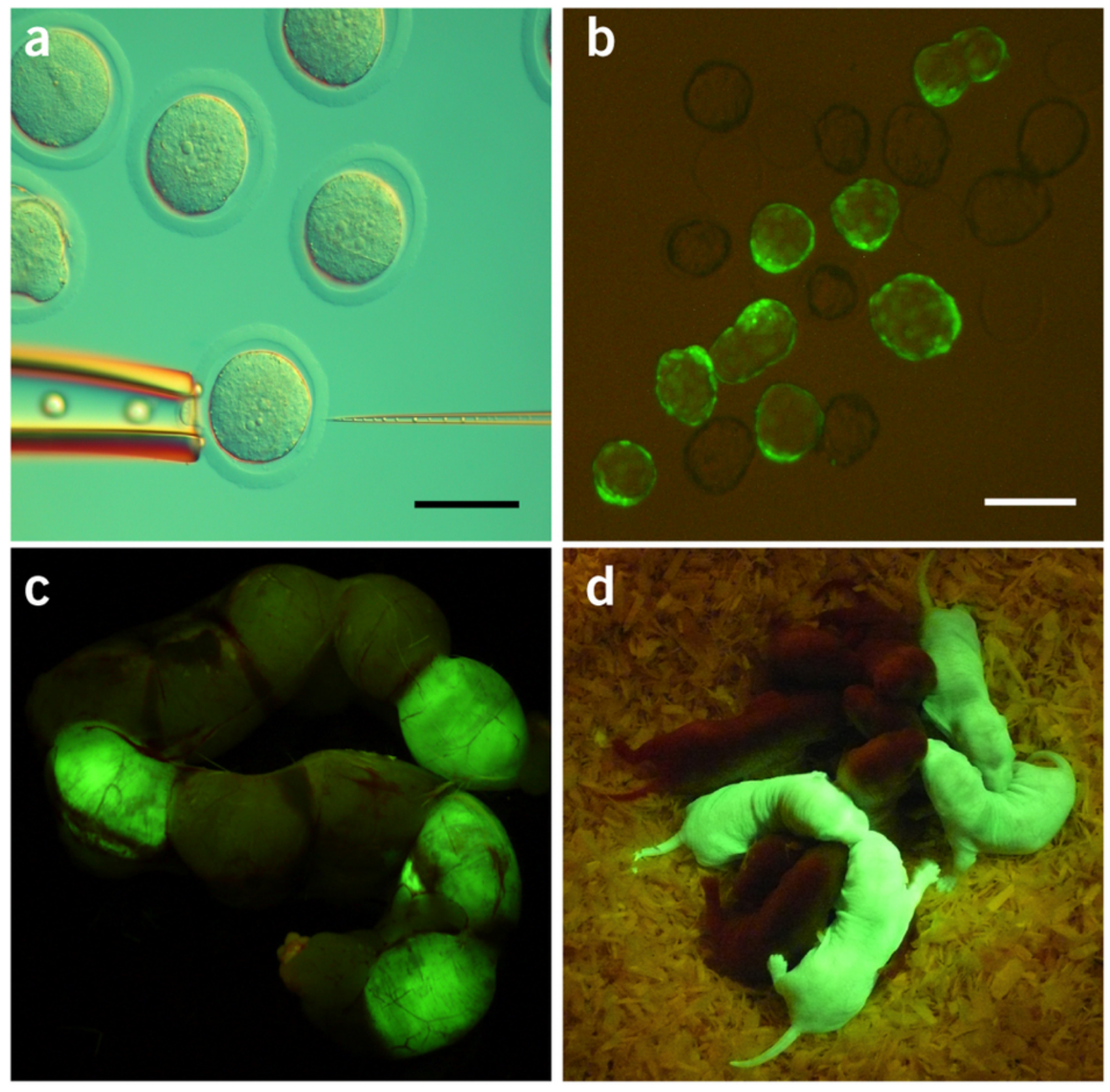

Figure 6. Derivation of transgenic rats with a Sleeping Beauty transposon vector encoding the Venus fluorescent protein. (A) Pronuclear microinjection of an ovum with the help of holding (left) and injection (right) capillaries; ova already injected are shown in the upper part; (B) Blastocysts at day 5 express the Venus transgene; (C) 14-day old fetuses expressing the Venus transgene; (D) 2-day old transgenic rats and their nontransgenic sibs. 


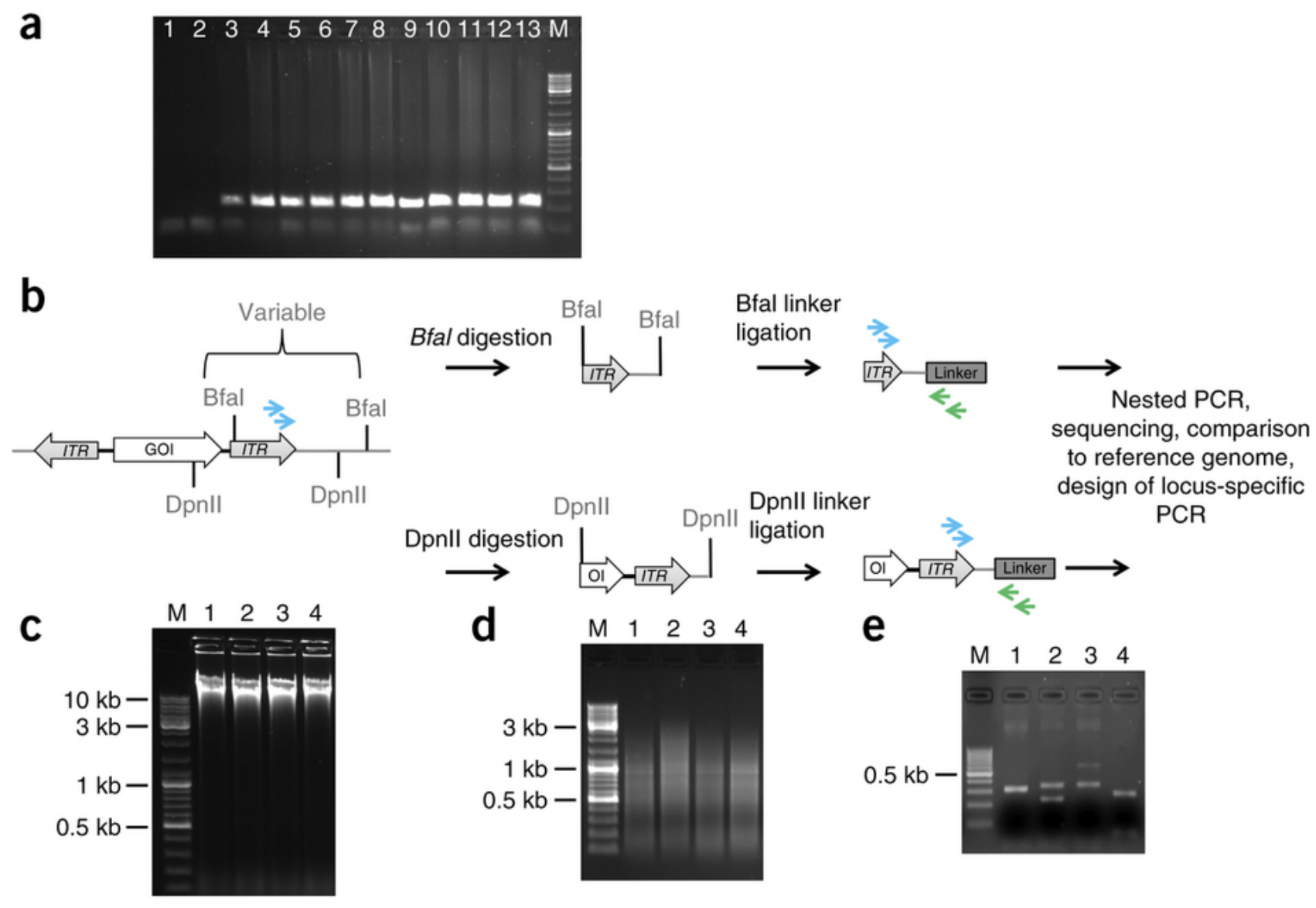

Figure 7. Identification of transgene integration by PCR. (A) Identification of integrated transposon sequences from genomic DNA samples by PCR with primers that amplify the left ITR of SB. Lanes: 1) $\mathrm{H}_{2} \mathrm{O}$; 2) mouse genomic DNA, negative control; 3) mouse genomic DNA, positive control; 4) transgenic founder \#1; 5-9) F1 offspring of transgenic founder \#1; 10) transgenic founder \#2; 11-13) F1 offspring of transgenic founder \#2; M) 100-bp molecular size marker. (B) Ouline of the LMPCR procedure.

Digestion of genomic DNA with the frequently cutting restriction enzymes Bfal and Dpnll and ligation of linkers with a known sequence allows for specific LMPCR amplification of transposon/genomic DNA junctions using primers specific to the transposon ITR (blue arrows) and the linkers (green arrows). Linker-to-linker amplifications are blocked by the 3' amino modifications on Linker(-) oligos (Table 1) ${ }^{69}$. Amplification products are then sequenced and compared to the reference genome. GOI, gene of interest; ITR, inverted terminal repeat. (C) Agarose gel with genomic DNA samples. Lanes 1-4) genomic DNA samples of rat founders, $500 \mathrm{ng}$ each; M) DNA size marker. (D) Agarose gel with genomic DNA 
samples digested with Bfal restriction endonuclease. Lanes 1-4) Bfal-digested DNA samples of rat founders, 200 ng each; M) DNA size marker. (E) Agarose gel with LMPCR products. Lanes 1-4) result of nested PCR following Bfal linker ligation; M) DNA size marker. 


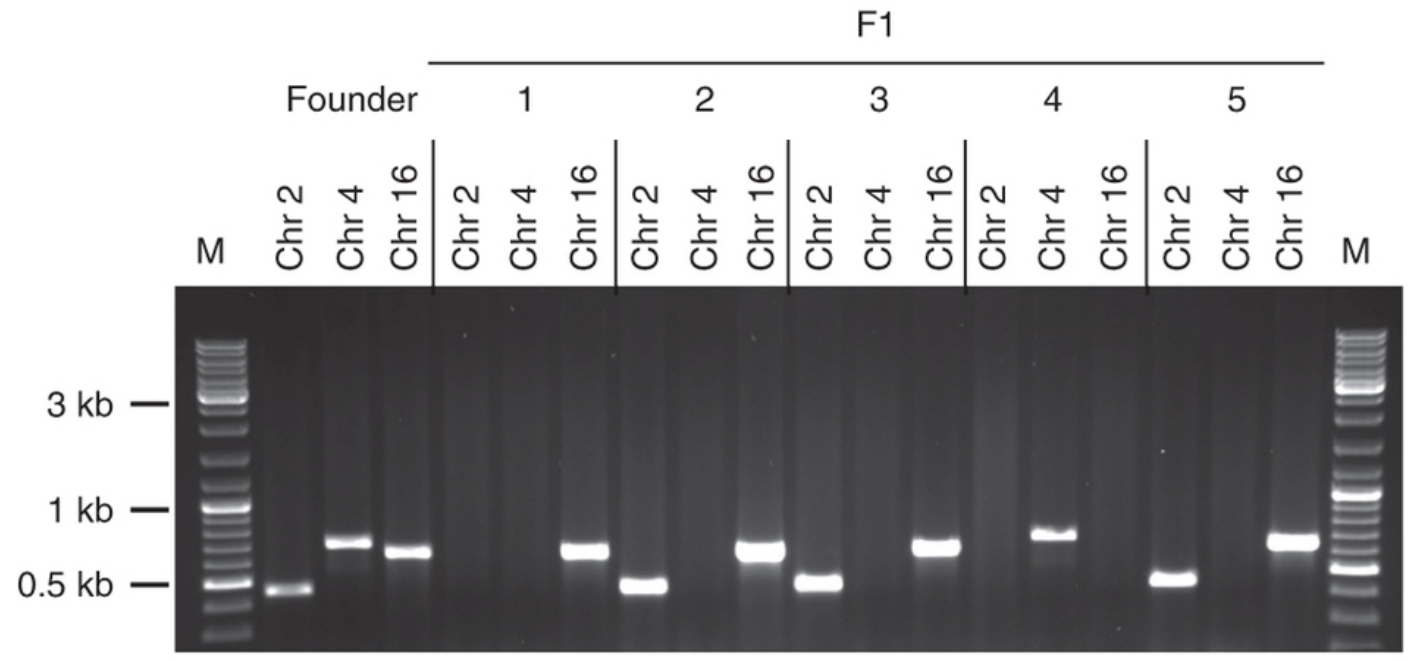

F1
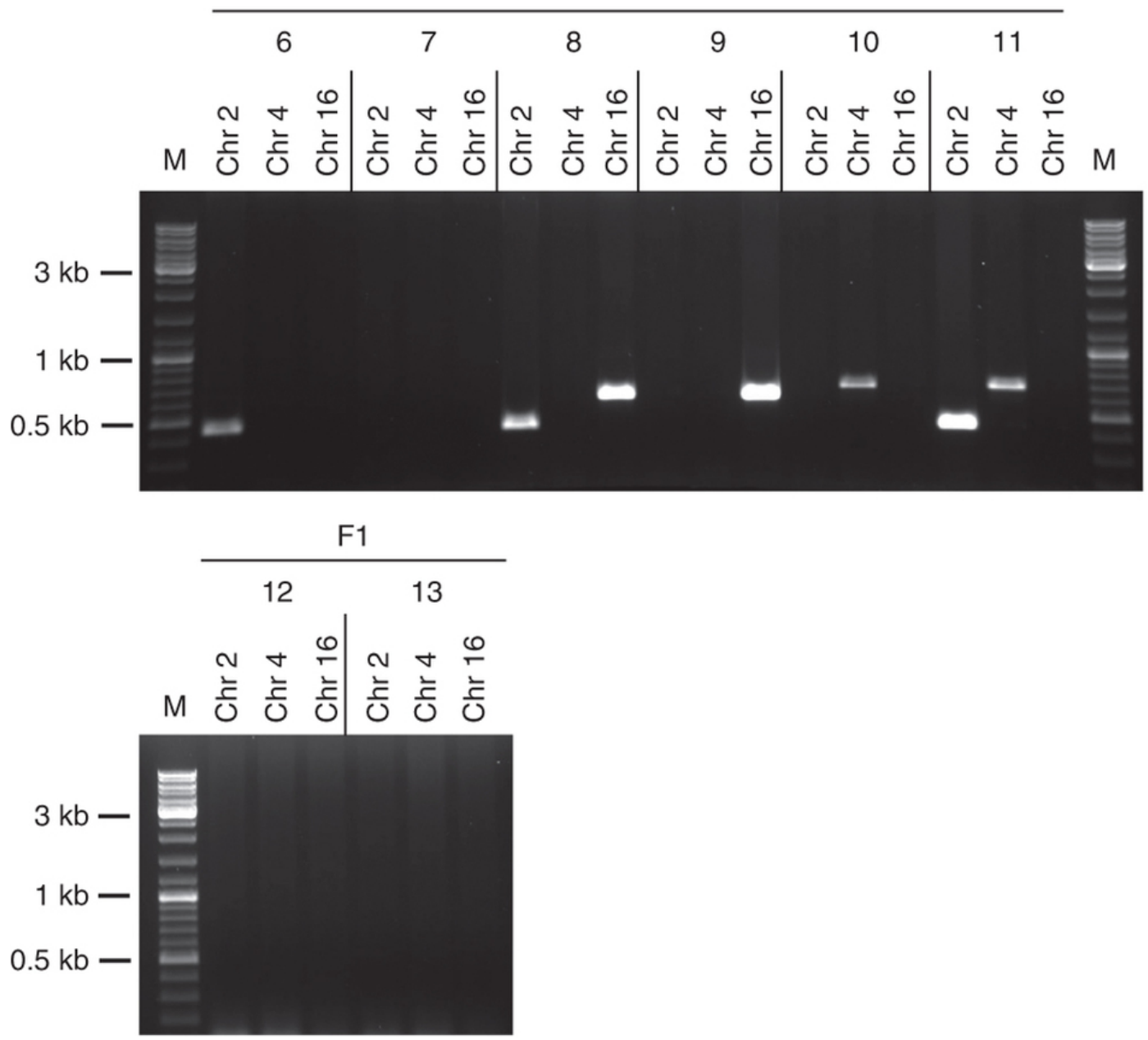

Figure 8. Locus-specific PCR test of a rat founder and its F1 descendants. The founder of these F1 rats carried three SB integrations (in chr2, chr4 and chr16), which were transmitted to the 13 descendants in different combinations. M, DNA size marker. 
Table 1. Primer sequences

\begin{tabular}{|c|c|c|}
\hline $\begin{array}{l}\text { Oligo } \\
\text { designation }\end{array}$ & Sequence & Description and use \\
\hline SB short & 5'-TACAGTTGAAGTCGGAAGTTTACATAC-3' & $\begin{array}{l}\text { Transposon-specific } \\
\text { primer used in PCR with } \\
\text { Tbal rev. Step } 75\end{array}$ \\
\hline Tbal rev & 5'-GAATTGTGATACAGTGAATTATAAGTG-3' & $\begin{array}{l}\text { Transposon-specific } \\
\text { primer used in PCR with } \\
\text { SB short. Step } 75\end{array}$ \\
\hline Linker(+) & $\begin{array}{l}\text { 5'-GTAATACGACTCACTATAGGGCTCCG } \\
\text { CTTAAGGGAC-3' }\end{array}$ & $\begin{array}{l}\text { Annealed either with } \\
\text { Linker(-) Bfal or Linker(-) } \\
\text { Dpnll to form double } \\
\text { stranded linker for LM- } \\
\text { PCR. Step } 89\end{array}$ \\
\hline Linker(-)Bfal & 5'-p-TAGTCCCTTAAGCGGAG-Amino-3' & $\begin{array}{l}\text { Annealed with Linker(+). } \\
\text { The 3' C7 amino } \\
\text { modification prevents } \\
\text { polymerase extension. } \\
\text { Step } 89\end{array}$ \\
\hline Linker(-)Dpnll & 5'-p-GATCGTCCCTTAAGCGGAG-Amino-3' & $\begin{array}{l}\text { Annealed with Linker(+). } \\
\text { The 3' C7 amino } \\
\text { modification prevents } \\
\text { polymerase extension. } \\
\text { Step } 89\end{array}$ \\
\hline Linker Primer & 5'-GTAATACGACTCACTATAGGGC-3' & $\begin{array}{l}\text { Linker-specific primer } \\
\text { used in the first round of } \\
\text { PCR with Tbal rev3s } \\
\text { (transposon specific). } \\
\text { Step } 92\end{array}$ \\
\hline Tbal rev3s & 5'-CATGACATCATTTTCTGGAATT-3' & $\begin{array}{l}\text { Transposon-specific } \\
\text { primer used in the first } \\
\text { round of PCR with } \\
\text { Linker Primer (linker } \\
\text { specific). Step } 92\end{array}$ \\
\hline Nested Primer & 5'-AGGGCTCCGCTTAAGGGAC-3' & $\begin{array}{l}\text { Linker-specific primer } \\
\text { used in the second } \\
\text { round of PCR with Tbal } \\
\text { (transposon specific). } \\
\text { Step } 94\end{array}$ \\
\hline Tbal & 5'-CTTGTGTCATGCACAAAGTAGATGTCC-3' & $\begin{array}{l}\text { Transposon-specific } \\
\text { primer used in the } \\
\text { second round of PCR } \\
\text { with Nested Primer } \\
\text { (linker specific). Step } 94\end{array}$ \\
\hline
\end{tabular}

